STEPHEN P. MAGEE

University of Chicago and Brookings Institution

\title{
U.S. Import Prices in the Currency-Contract Period
}

EVENTS IN INTERNATIONAL MONEY MARKETS since 1971 have aroused considerable interest in the effects of changes in foreign exchange rates on trade patterns. In any theoretical approach, the prices of traded goods are crucial to economic activity following devaluation. Because the quantities of exports and imports may be inflexible for a time following a devaluation, price changes determine the movement in the trade balance in the short run. "Currency-contract analysis" deals with the first round, or impact, effect of devaluation on the prices of internationally traded goods that cross national boundaries after devaluation but that were contracted for before it took place. ${ }^{1}$ The crucial determinant of this effect on the trade balance is whether these contracts are denominated in home currency or in foreign currency.

My earlier paper in this journal stressed that the initial decline in the trade balance that countries sometimes experience following devaluation

Note: I am indebted to the Rockfeller Foundation and the National Science Foundation for research support; to Rudiger Dornbusch, George N. Ecklund, Norman S. Fieleke, Otto Kiehn, Max Lechter, Colleen Ledgerwood, Stephen Nyschot, Paul Wonnacott, and participants in the Brookings panel and in the Workshop in International Economics at the University of Rochester for helpful comments; and to Deborah DuBourdieu, Jeffrey J. Schott, and especially Ellen Hahn for research assistance.

1. See Stephen P. Magee, "Currency Contracts, Pass-through, and Devaluation," Brookings Papers on Economic Activity (1:1973), pp. 303-23. 
(referred to as the "J-curve" in the press) is not a theoretical inevitability. For example, if U.S. import contracts are denominated in dollars and U.S. exports are denominated in foreign currency, the U.S. trade balance would increase rather than decrease immediately following a devaluation of the dollar, and the J-curve would not appear. The reason is that the value of U.S. import contracts would remain constant in dollars; however, since devaluation implies a higher dollar value of foreign currency, outstanding U.S. exports contracted in foreign currency would yield a higher price in dollars. The J-curve result-that is, an immediate decline in the trade balance following devaluation-will always ensue if the proportion of contracts denominated in foreign currency is higher for imports than for exports (given an initial trade deficit).

What little empirical evidence there is on currency contracts is consistent with the J-curve. Grassman found that in 1968, 66 percent of Swedish exports were denominated in kroners while 25 percent were in the purchasing country's currency; 59 percent of the import contracts were denominated in the selling country's currency while 26 percent were denominated in kroners. ${ }^{2}$ The symmetry noted by Grassman is important: roughly twothirds of contracts were in the seller's currency and one-fourth in the purchaser's. With the proportion of contracts denominated in foreign currency higher for imports than for exports, devaluation by Sweden would be expected to lead to an initial decline in that country's trade balance. ${ }^{3}$ Grassman also investigated the bilateral pattern of currency contracts between Sweden and a number of her major trading partners. He found that 94.3 percent of Swedish imports from the United States and Canada were in the exporting country's currency, while 64.5 percent of Swedish exports to the United States and Canada were in the importing country's currency. Although this pattern differs from that of Sweden's total trade, devaluation by Sweden still results in an initial deterioration in Sweden's bilateral trade balance with these two countries.

Since the currency contracts of U.S. trade have not been studied heretofore, this paper is a pilot study of the currency of denomination and the

2. See Sven Grassman, Exchange Reserves and the Financial Structure of Foreign Trade (Lexington Books, 1973), and Sven Grassman, "A Fundamental Symmetry in International Payment Patterns," Journal of International Economics, Vol. 3 (May 1973), pp. 105-16.

3. If the devaluing country's trade balance is measured in terms of foreign currency, it declines as well, since the capital gain on imports is small relative to the capital loss on exports. 
length of contracts. Time and data limited this study to U.S. imports from Japan and West Germany. These countries were selected for two reasons. First, they are second only to Canada as trading partners with the United States; in 1971, Japan supplied 16 percent of U.S. merchandise imports and Germany supplied 8 percent. Second, as Figure 1 indicates, the parity changes of the yen and the deutsche mark vis-à-vis the dollar have been large since $1971 .^{4}$

The paper is organized in the following manner. The first section describes the sample of customs invoices used in this study for U.S. imports from Japan and Germany in two U.S. fiscal years, 1971 and $1973 .{ }^{5}$ About two-thirds of U.S. imports from Japan are denominated in dollars while four-fifths of imports from Germany are in deutsche marks. Thus, U.S. imports from Japan conform to the pattern established in Grassman's study of those from Sweden, while U.S. imports from Germany reverse it.

The next section reports calculations of the three lags between orders and deliveries of Japanese and German goods to the United States: the production lag, the transportation lag, and the entry lag. The sum of these three lags determines the length of the currency-contract period for U.S. importers. In the following section, frequency distributions and cumulative distributions of the length of the currency-contract period for U.S. importers and foreign exporters, considering both currencies, are used to determine the effects of devaluation on U.S. import prices and on foreign export prices attributable in 1971-73 to the currency denomination of contracts outstanding at the time of devaluation.

I then examine three errors in the 1971-73 statistics on the U.S. balance of payments for the currency-contract period that are caused by the regulations followed by the U.S. Bureau of Customs in measuring imports. The first is the tendency to ignore the currency of the import contract and

4. When changes in exchange rates are not large, it is difficult to detect any passthrough of the price effects after the currency-contract period. See, for example, Robert M. Dunn, Jr., "Flexible Exchange Rates and Oligopoly Pricing: A Study of Canadian Markets," Journal of Political Economy, Vol. 78 (January/February 1970), pp. 140-51. Dunn's study covered the period of the flexible Canadian exchange rate and focused on six products in which competition was less than perfect. The evidence is not uniform, however. A study by John R. Dominguez, Devaluation and Futures Markets (Lexington Books, 1972), found that anticipation of the 1967 devaluation of British sterling was reflected in cocoa futures in New York and London. In this case, pass-through of the relative price effects began before the devaluation.

5. Hereafter, these years will be referred to without the designation "fiscal year." When calendar years are meant, the text will so state. 


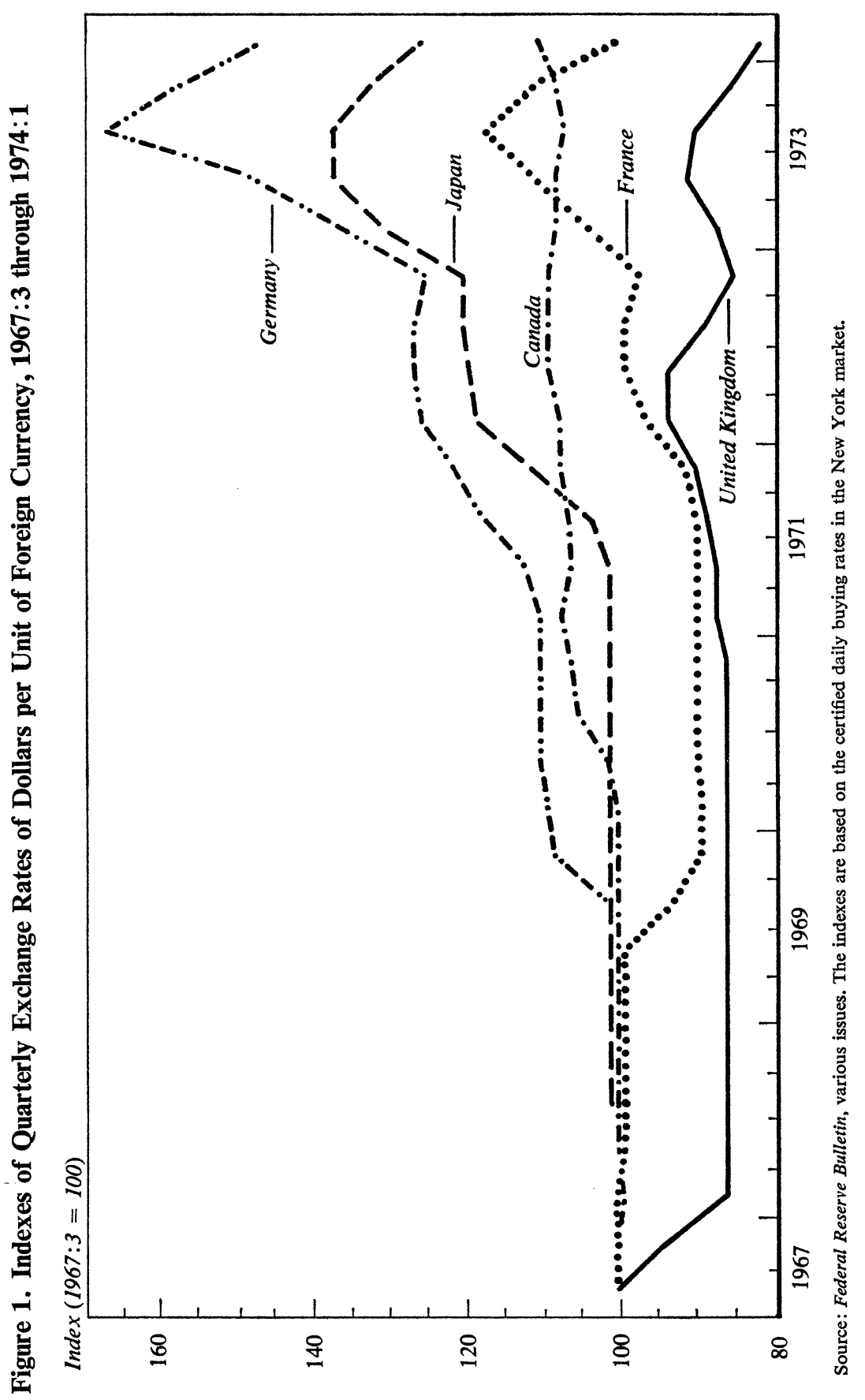


to mark up all imports by the amount of the devaluation. The second arises from the stickiness in the statutory rate of exchange used to value imports. The third is the valuation of imports at the time of foreign export rather than of arrival in the United States. In a period in which the dollar is depreciating, the first error causes an overstatement of U.S. imports, while the second and the third cause an understatement.

A final section summarizes the paper.

\section{The Currency Denomination of Contracts}

\section{THE DATA}

The data used in the study below are taken from a sample of a 1 percent sample of U.S. customs invoices for imports from West Germany and Japan in U.S. fiscal years 1971 and 1973. The 1 percent sample is catalogued by the fiscal year in which the documents are liquidated. ${ }^{6}$ Because of the long lag in liquidations for some items, a given fiscal year may contain invoices covering exports from the foreign country to the United States that took place one to two years earlier.

Because of the time and expense required to tabulate the information on currency contracts and the various lags involved in the currency-contract period, the sample used in this study was, of necessity, small. For U.S. imports from Japan, 176 and 173 invoices were drawn from the 1 percent sample for 1971 and 1973, respectively; for Germany, 76 and 139 invoices were drawn. There were thus 349 observations for Japan and 215 observations for Germany, or an overall sample size from both countries of 564 observations. Because of the confidentiality of some of the data on the invoices, I was provided tabulations only of the denomination of the contracts, the lags involved, and so on, but no information that would permit

6. The U.S. Bureau of Customs collects import statistics in two steps. First, when the importer obtains possession of the imported goods, he must file all of the documents related to the transaction and pay estimated duties plus a bond on the goods being imported. The date of these actions is the "entry date." All customs invoices are then checked by the bureau for the accuracy of the information, the correctness of the amount of duties paid, and so on. The completion of this checking marks the "liquidation date." The time required for liquidation ranges from about one month to several years, depending on whether there is a change in valuation, classification, and other factors affecting duty liabilities at the time of entry. (The mean and median liquidation times were 150 days and 142 days, respectively, for U.S. imports from Japan in the 1973 sample.) The goods are reported in the U.S. import statistics at the time of entry. They are revised only if large changes are made at the time of liquidation. 
identification of the parties involved in the transaction. Both the value and the quantity of each transaction were, unfortunately, excluded.

Ten to fifteen invoices were requested for several products of special interest imported from each of the countries; twenty to forty invoices were chosen at random to represent all other goods. Since this procedure means that some goods were overrepresented and others underrepresented, the aggregate means and frequency distributions for the variables used in this study were obtained by taking weighted averages of the variables and the frequency distributions from the component samples.

Fourteen major imports from Japan were chosen for examination and ten from Germany. In 1971, these products represented, respectively, 49.4 percent and 59.3 percent of U.S. imports from the two countries, based on the four-digit classes of the Standard International Trade Classification system (SITC). The products for which samples were drawn are those that bear an asterisk in columns (3) and (4) of Table 1. These columns report the share of the goods in U.S. imports from Japan and Germany in 1971. The sample of customs invoices was drawn on a seven-digit TSUSA basis (the Tariff Schedules of the United States Annotated, the scheme used to classify the U.S. import documents). Thus, particular products within the TSUSA categories were assumed to represent the entire four-digit SITC product category. All weighting done in this paper uses four-digit SITC weights. The share of the seven-digit TSUSA items in total imports from each of the two countries is given in columns (5) and (6) of Table 1. Columns (7) and (8) show the importance of the seven-digit products from which the sample is drawn relative to the four-digit SITC categories that they represent.

Within each of the TSUSA categories, I specified a desired number of invoices for each product from each country for each year. The sample was stratified according to the port of entry for the product. For each product, I requested that the invoices provided be proportional to the share of that good from the exporting country entering each of the three most important ports of entry in the United States and to a fourth share comprising all other ports. Because of the small number of invoices available from the 1 percent customs sample, this stratification was not always possible.

\section{THE CURRENCY DENOMINATION OF IMPORT CONTRACTS}

The currency in which the import contract is denominated is important for several reasons. First, if a U.S. import is contracted in dollars, the 
foreign exporter either takes the foreign exchange risk or hedges the transaction. If the contract is in foreign currency, the U.S. importer takes the risk or hedges. Second, in the absence of hedging, an unanticipated devaluation of the dollar leads to a capital loss for foreign exporters when the contract is in dollars or a loss by U.S. importers when the contract is in foreign currency.

Information on the currency denomination of the contracts examined in this study was taken from U.S. Customs Form 5515, the Special Customs Invoice. It is usually filled out by the foreign supplier and requires that he state the currency in which the shipment was invoiced. Almost all invoices from Japan are invoiced in dollars, while a large proportion of imports from Germany are invoiced in deutsche marks.

The currency of the contract is not necessarily the same as that used in invoicing the goods. It would not be, for example, if the exchange rate is fixed in the contract. On the special customs invoice, the shipper is required to state whether the exchange rate was set in the contract; and, if so, what it is. If the exchange rate is guaranteed, the true currency denomination of the contract is not that in which the shipment is invoiced. If the response does not indicate a set rate, the currency of the invoice and the currency of the contract are presumed to be the same. A sizable minority of the dollar-invoiced transactions from Japan to the United States used a fixed exchange rate so that these contracts were in yen.

From the information on these two matters reported on the special customs invoice, I have constructed the currency denomination of the contracts for U.S. imports in the sample. The results, shown in Table 2, indicate that when the proportions of the invoices for each product category are weighted by their share in imports for the product category, threefifths to three-fourths of U.S. imports from Japan, and one-eighth to onefourth of U.S. imports from Germany, were in dollars in 1971 and 1973. The Japanese results are in line with those obtained by Grassman for U.S. imports from Sweden, while the German results are not. ${ }^{7}$

One interesting feature revealed by Table 2 is the 1971-73 increase in the proportion of U.S.-Japanese trade denominated in dollars from 61 to 72

7. As noted above, Grassman found that two-thirds of all contracts in Swedish trade were denominated in the seller's currency ("A Fundamental Symmetry," pp. 110-11).

However, his finding that nearly two-thirds of U.S. and Canadian imports from Sweden were in dollars reverses the comparison, so that Japan conforms to his bilateral results while Germany does not. 


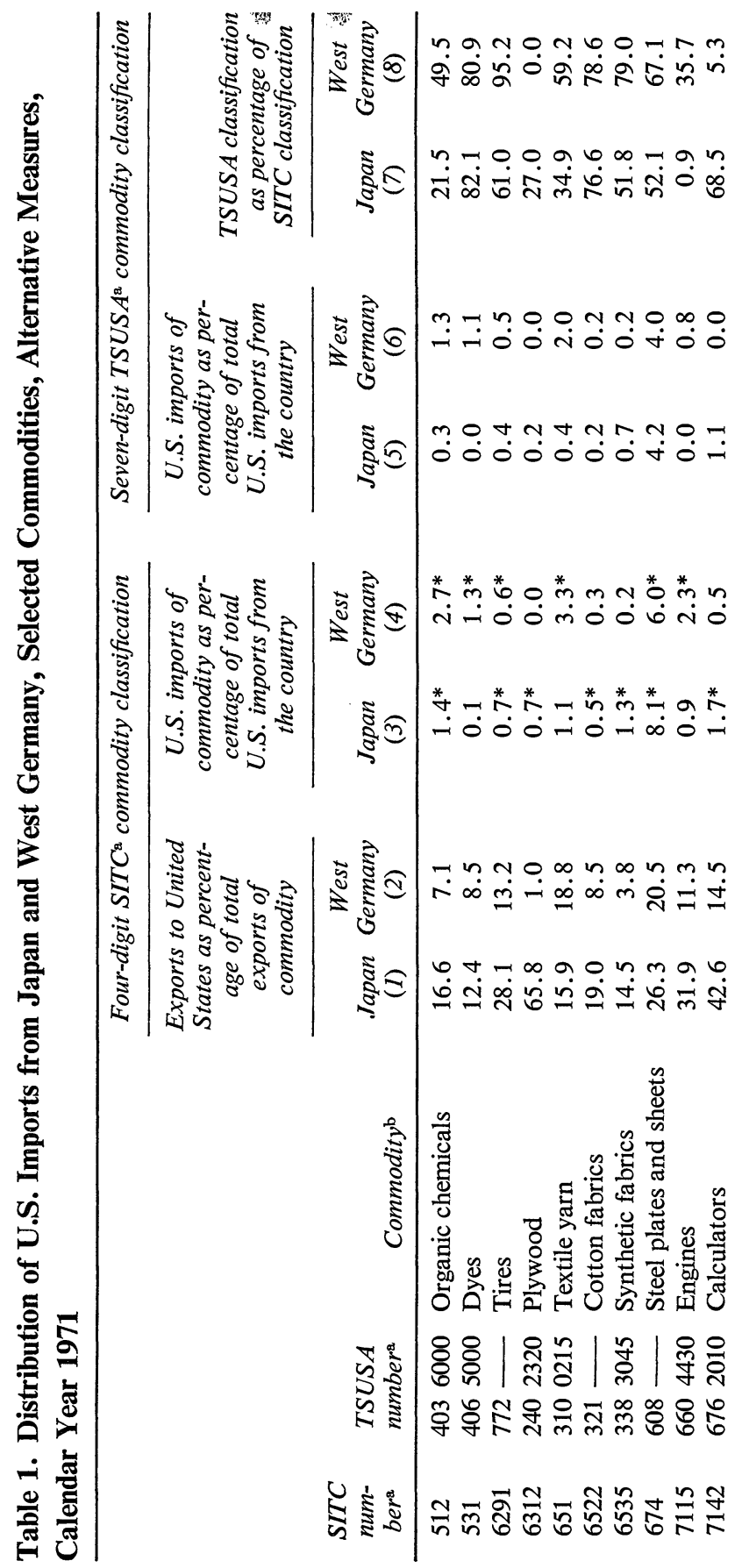




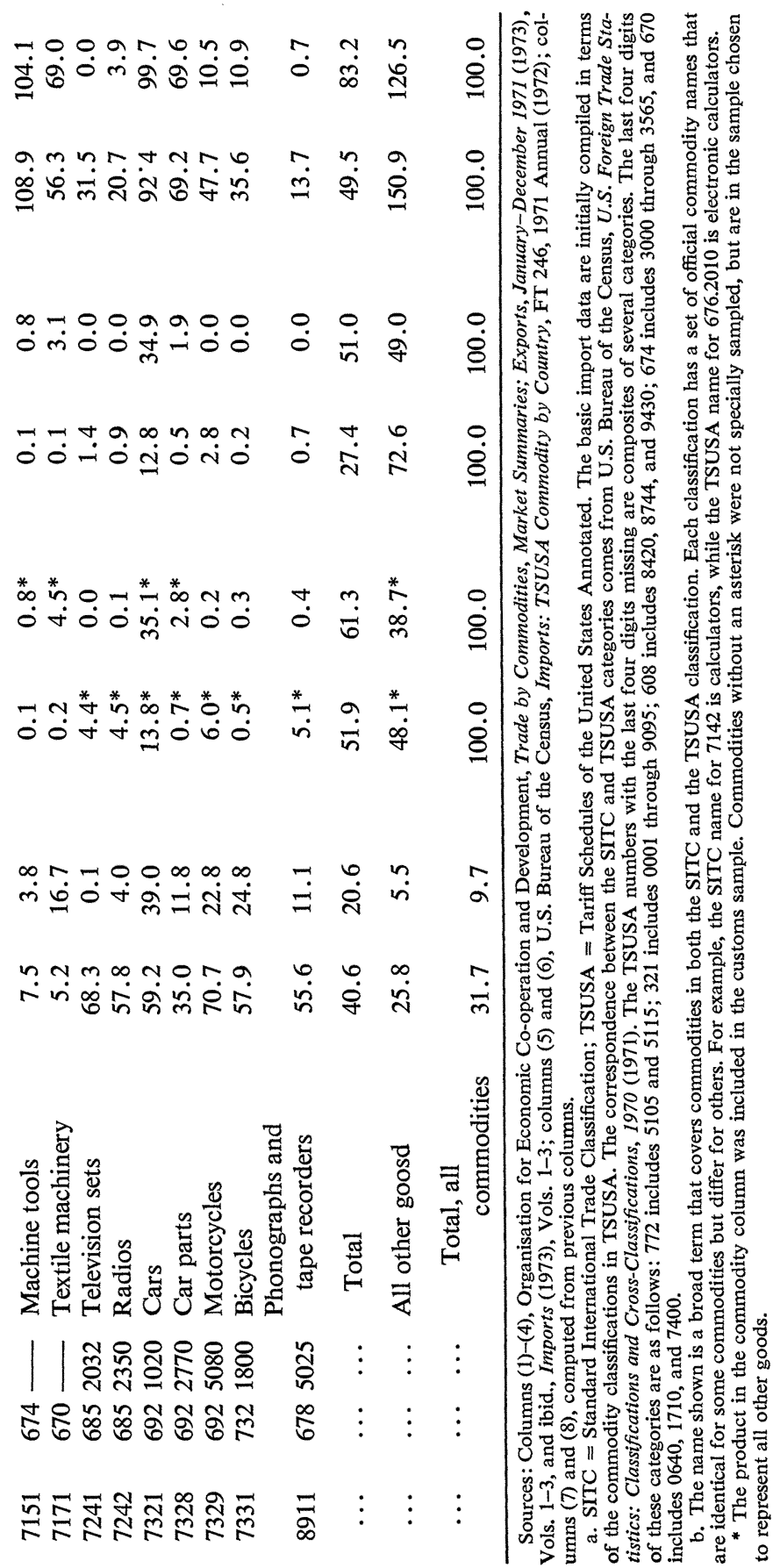




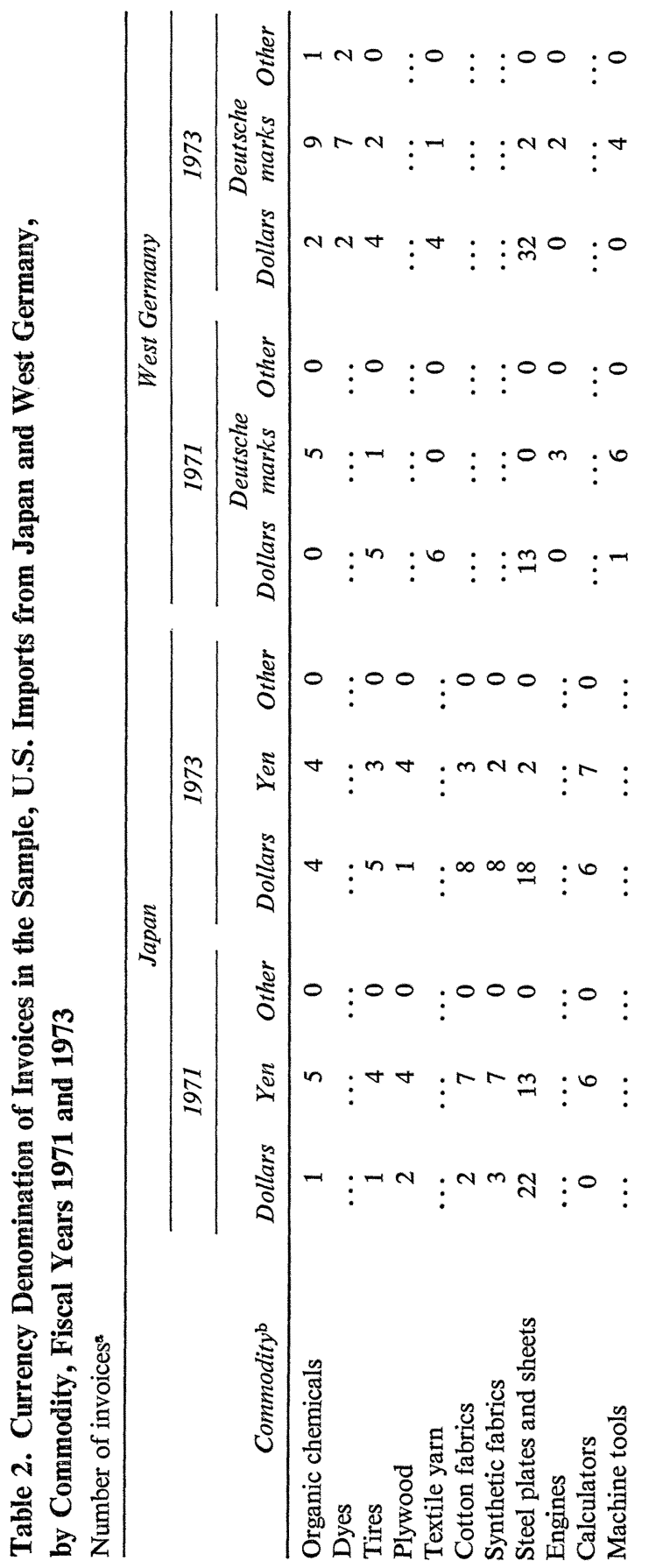




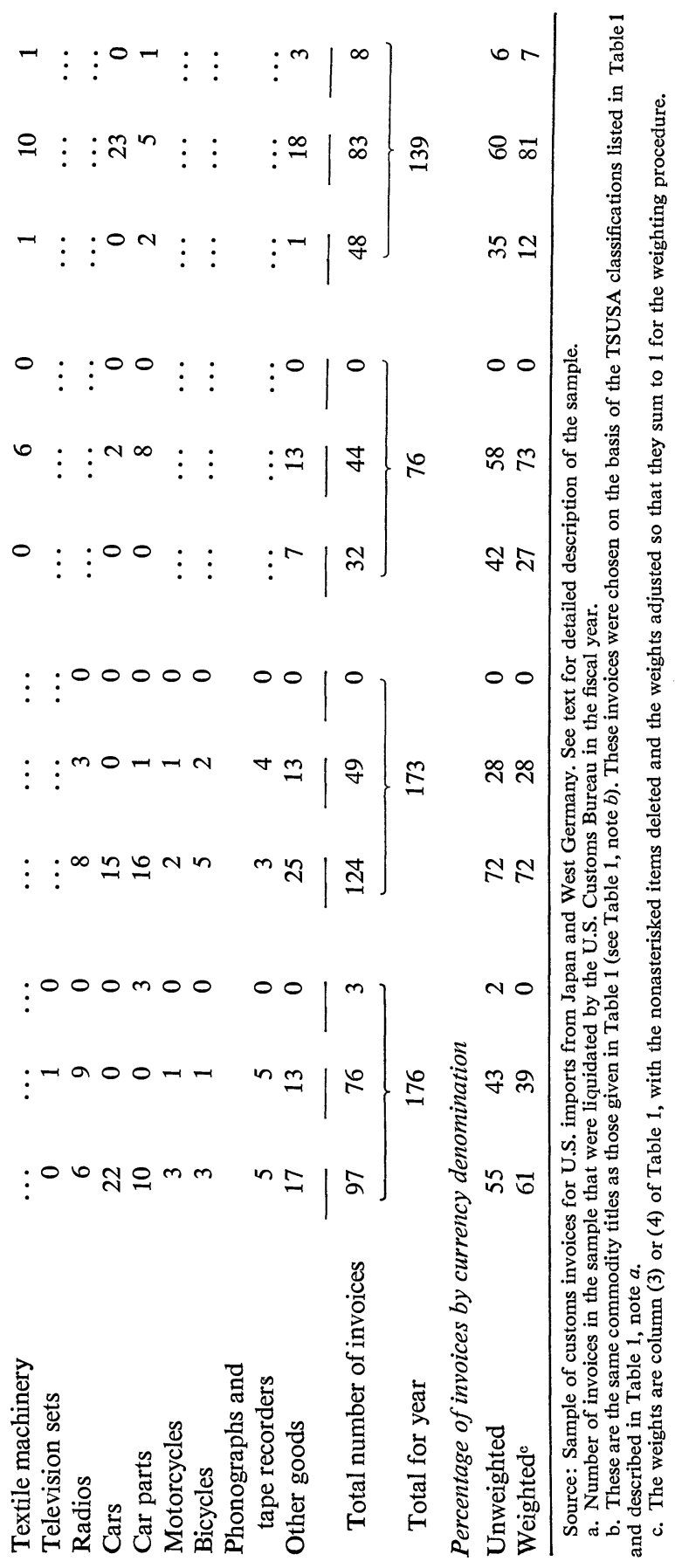


percent on the weighted basis. This increase is due mainly to the heavier proportion in the "other goods" category (although sampling error may account for part of it). However, the proportion in dollars also rose in several product categories: organic chemicals, tires, fabrics, steel, calculators, and radios. Thus, the devaluation of the dollar relative to the yen in late 1971 did not lead to a decrease in the proportion of Japanese exports contracted in dollars, as might have been expected, but the reverse. In the case of Germany, however, the proportion of U.S. import contracts denominated in dollars was smaller in 1973 than in 1971.

Table 2 also permits comparisons by product between the currency contracts of U.S. imports from Japan and Germany. The exporter's currency generally is used for organic chemicals from both countries, while steel from both is contracted in dollars. Imports of autos and auto parts from Japan tend to be denominated in dollars, while those from Germany are in deutsche marks. U.S. imports of tires from Japan are about evenly divided in their currency denomination, while those from Germany are mostly in dollars.

Table 2 presents the unweighted as well as the weighted proportions of invoices in each currency. The weighting procedure tends to raise slightly the proportion of contracts from Japan denominated in dollars, and to increase dramatically the proportion of invoices from Germany denominated in deutsche marks. In both cases, the result depends heavily on the relative proportion of contracts in each currency in the major product items, such as automobiles and other goods.

\section{EXPLANATIONS OF THE CURRENCY OF CONTRACTS}

I have made no systematic effort to explain the tendency for U.S. imports from Japan to be denominated in dollars while imports from Germany are denominated in deutsche marks. The discussion in this section is, rather, based on conversations with traders, bankers, and others who have some knowledge of these transactions, and is thus largely qualitative.

Tradition and habit are frequently cited as the determinants of the denomination of contracts for individual products. However, for trade as a whole, the stability of exchange rates is an important element. The proportion of German exports to the United States in dollars was larger before the revaluations of the deutsche mark in 1961, 1969, and 1971. Since 1961, German exporters have moved away from invoicing in dollars, 
fearing that unanticipated revaluations of the deutsche mark would cause capital losses on their outstanding contracts. Because of the extremely long postwar period during which the parity of the dollar to the yen did not change, Japanese exporters felt that the risks involved in denominating in dollars were relatively small. In consequence, most Japanese exports to all countries are denominated in dollars.

Another conceivable explanation for the difference between the practices of the two countries is that Japanese exporters may be less risk averse than U.S. importers while German exporters are more risk averse.

Still another explanation is the competitive factor, which provides several arguments. To the extent that sellers are more concentrated than buyers and therefore have greater market power, they will denominate in their own currencies in order to avoid exchange risks or the costs of hedging. ${ }^{8}$ The accentuation of the pattern of currency contracts from 1971 to 1973 suggests that whatever market power was at work in determining the 1971 share of contracts in dollars had an even stronger influence following the adjustments in exchange rates. On the other hand, the currency denomination of contracts may be used by sellers to adjust their market shares. For example, according to Table 2, U.S. imports of automobiles from Japan are denominated largely in dollars, while autos from Germany are denominated in deutsche marks. To the extent that the currency of the contract is a competitive element, this pattern might imply that Japan has not achieved its long-run target share in the U.S. market while Germany has already done so. The increase in the proportion of contracts with Japan denominated in dollars could indicate that the Japanese were using this means to favor U.S. importers so as to offset the decline in their competitiveness induced by the dollar devaluation. Such an explanation does not apply to Germany, since the proportion of contracts in deutsche marks for trade as a whole rose from 1971 to 1973 , although probably not by a statistically significant amount.

Two factors related to financial markets may help to explain the tendency for the Japanese to denominate in dollars. First, some Japanese banks may

8. In "Currency Contracts," p. 313 , I speculated that since exports are more heavily concentrated than imports-on this point, see Michael Michaely, Concentration in International Trade (Amsterdam: North-Holland, 1967)-exporters will tend to be in a stronger bargaining position, abstracting from other considerations. While the stronger party can exercise his power in many ways, to the extent that he does so in connection with the currency denomination of contracts, Grassman's finding that two-thirds of contracts tend to be denominated in the seller's currency is explained. 
have been encouraged to finance contracts in dollars because such contracts are exempted from some of the tight credit controls exercised by the Bank of Japan. In the postwar period, the Japanese government actively subsidized activities that would increase dollar earnings, so that financing programs were biased toward dollar-denominated contracts. Second and less important, the finance charges that banks can levy on yen-denominated contracts are smaller than the charges allowable for dollar-denominated contracts. The banks would thus prefer dollar-denominated contracts, while borrowers would prefer yen-denominated contracts. The net effect of these two tendencies is reported to be a bias toward dollardenominated contracts.

\section{Lags in the Currency-Contract Period}

The length of the currency-contract period for U.S. importers depends on three lags between orders of foreign merchandise and their delivery at the port of entry in the United States: the production lag, the transportation lag, and the entry lag. These three lags are shown schematically in Figure 2. The sources of the dates used to determine them are two forms filed at the times goods enter the United States, as defined below. On the Special Customs Invoice (Customs Form 5515) the foreign seller must state the date on which he accepted the order from the United States. The date of exportation, the date of importation, and the date of entry into the United States are shown on a second form, the Consumption Entry (Customs Form 7501), which is filled out by the U.S. importer or his agent. The date of exportation is the date on which a carrier moving goods to the United States leaves the country of exportation. The date of importation is the date when a ship arrives within the customs port at which the goods will be unloaded, or the date when cargo carried over-

Figure 2. The Three Components of the Importer's Currency-Contract Period

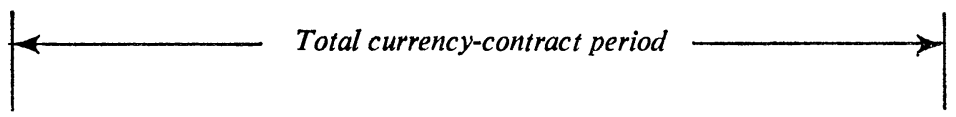

Date order is accepted by foreign producer

Date of exportation

Date of

Entry

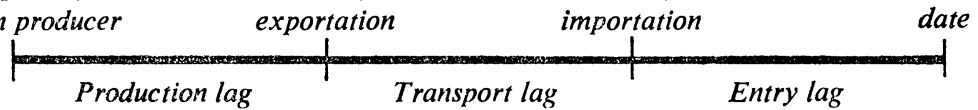

Sources: Based on U.S. Bureau of Customs forms, Special Customs Invoice (Customs Form 5515) and Consumption Entry (Customs Form 7501). 
land or by air arrives within the customs territory of the United States. After the goods arrive, they are "entered." The entry date is the time when the importer or his agent posts with the Customs Bureau all the required documents, "estimated duties," and a bond to cover any underestimate of duty liabilities that might be discovered subsequently. If arrangements have been made in advance, goods can be released before entry, or upon "immediate delivery." This means that they have been cleared to enter the possession of the importer even though he has not yet paid any duties. He has up to ten days from receipt of the goods in which to file all entry forms and pay the estimated duties. This provision greatly facilitates trade for firms that receive many shipments and speeds the passage of goods across the borders from Mexico and Canada.

The terms used to describe the lags should not be taken literally. The production lag is merely the period between acceptance of an order and export. It includes the full manufacturing time only when the product is made to order or to specifications that cannot be anticipated; it may be short for standardized products that are mass produced in anticipation of orders. ${ }^{9}$ The production lag is thus determined by many forces, including the flow of orders expected by the producer, the extent to which the seller speeds delivery as a way of improving his competitive position, storage costs, and the number of unfilled orders. The transportation lag is self-explanatory. However, the entry lag-the lag between the date of importation and the entry date-may comprise at least three elements: unloading the ship, the ten-day grace period for filing the entry form for goods entered under immediate delivery, and the transshipment time between the port of importation and the port at which the goods are entered. For example, goods that come through Houston for an importer in Toledo, Ohio, may be transshipped to the Toledo port of entry for his convenience in paying the estimated duties and bond.

Using the invoice sample described in Table 2, I have calculated the three lags in the currency-contract period: the average and median lags by product are shown in Table 3 for Japan and Table 4 for Germany. The

9. These goods may or may not be held in inventories in the exporting country. One U.S. customs official reported that the Japanese will load standardized goods on ships bound for the United States, even though orders have not been received for them. If an order is received while the goods are en route, the Japanese shipper will radio the ship, indicating where the goods are to be unloaded. If no order is received, they will be placed in warehouses at one of the scheduled ports of unloading. Underlying this anecdote are two factors: the ability of the Japanese to compete effectively by anticipating orders and the high relative cost of warehousing in Japan. 


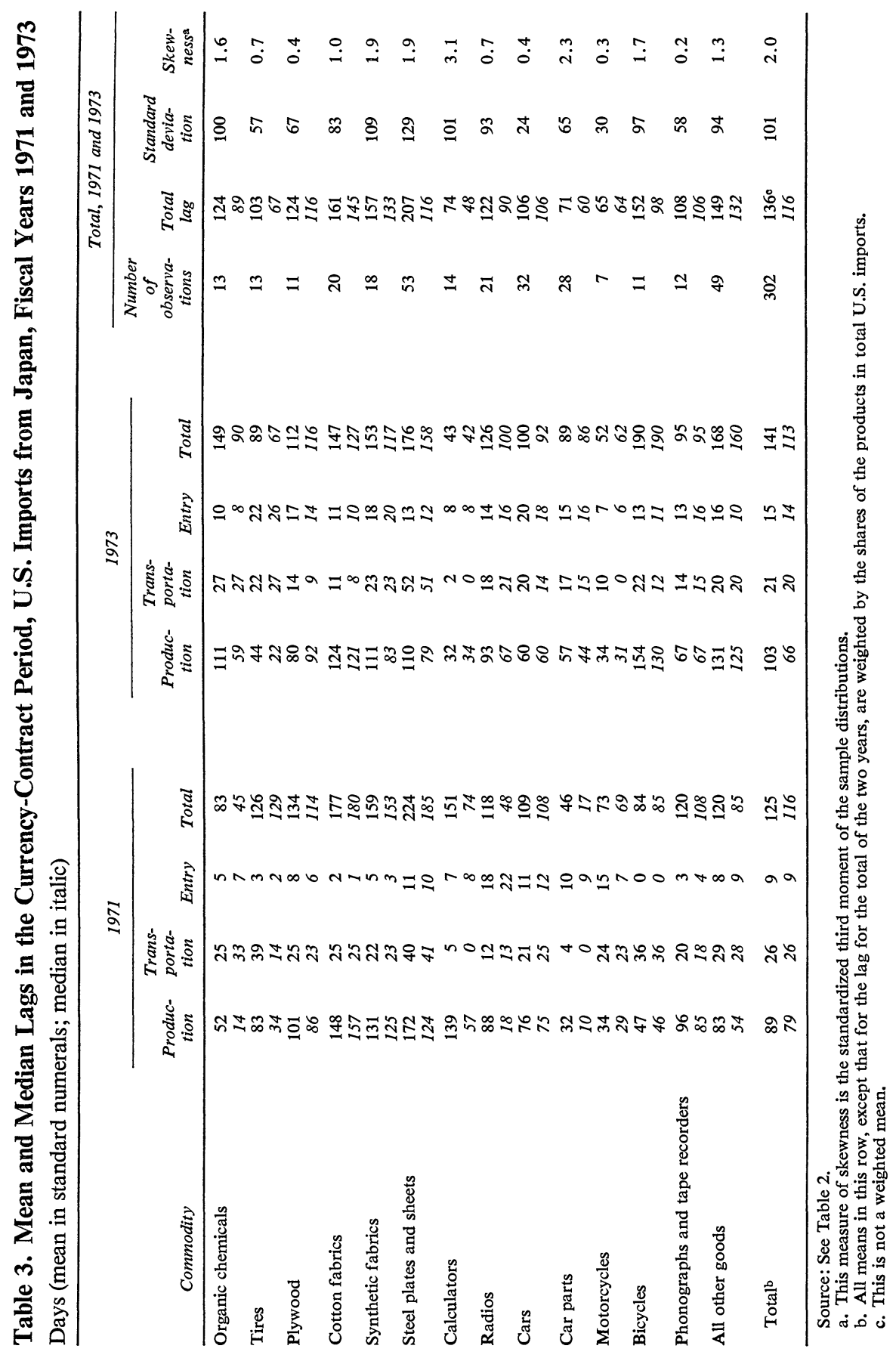




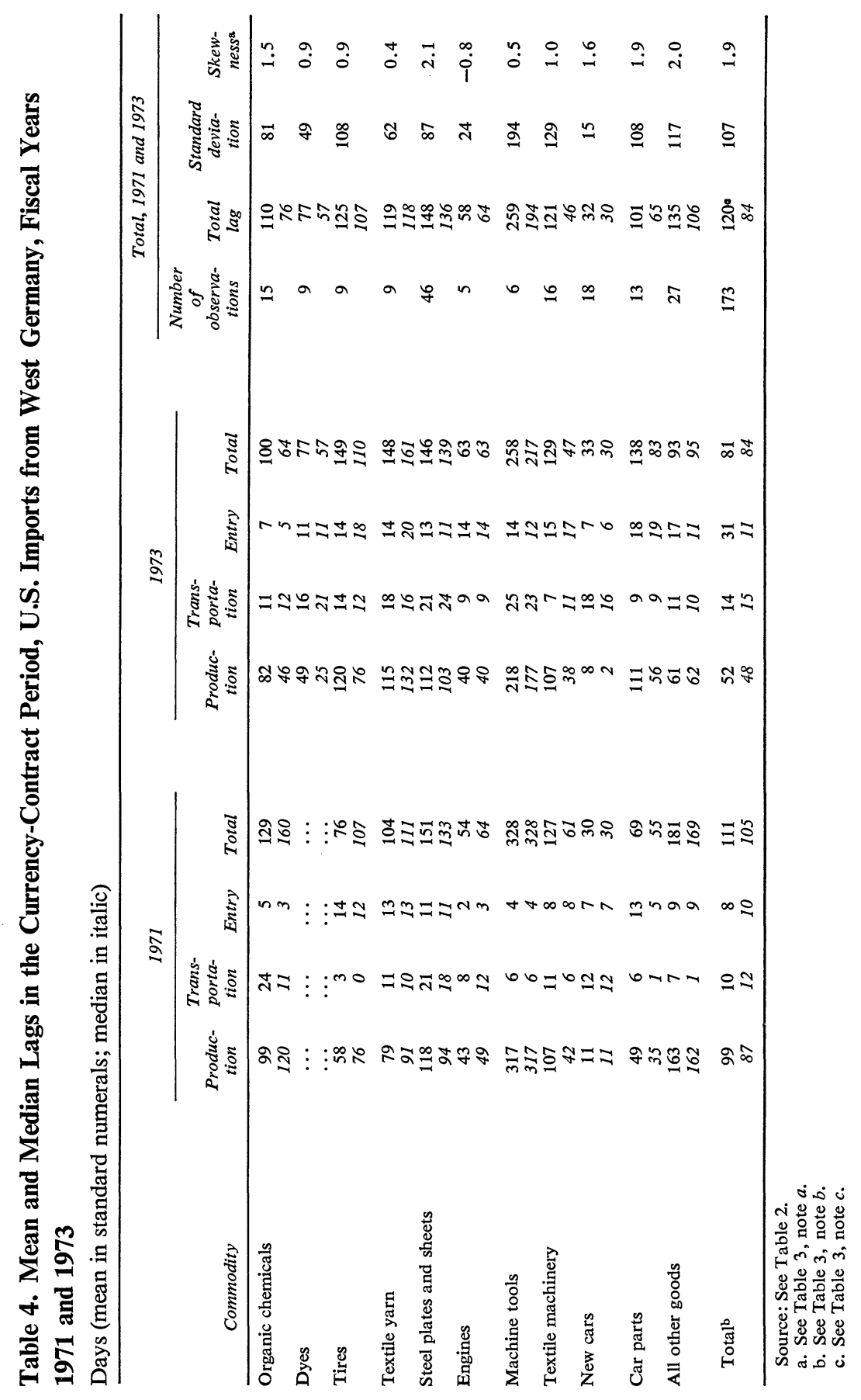


production lags for U.S. imports from Japan tend to be consistently long for plywood, cotton fabrics, synthetic fabrics, and steel. The shortest transportation lag is for calculators: The mean was 5 days in 1971 and 2 days in 1973; the median is zero for both years because of the heavy use of air freight (three-fifths of the imports of Japanese calculators in 1972 came by air). ${ }^{10}$ The longest average transportation lag is for steel. This may be due to stops on the way from Japan, the route taken, the importance of nonWest Coast ports as ports of unlading, or other factors. The total currency-contract period for U.S. imports from Japan tends to be short for calculators, car parts, and motorcycles. The longest is for steel.

Table 4 reveals a strikingly short lag between orders and deliveries of automobiles from Germany. The cause is the very short production lag, which may be due to statistical artifact, inventories available for export, or other factors. Since autos compose over a third of U.S. imports from Germany, the average length of the German currency-contract period is shorter than Japan's. The atypically long lag in the delivery of German machine tools is also of interest. This lag is not out of line with those calculated by Artus for the United States and the United Kingdom in 1971. ${ }^{11}$

Another notable fact is the slight increase from fiscal year 1971 to 1973 in the order-to-delivery lag for imports from Japan while the lag for imports from Germany narrowed by one month.

The last four columns of Tables 3 and 4 provide summary statistics from

10. U.S. Bureau of the Census, "U.S. Imports for Consumption and General Imports," IA 236-Part 1 (Comparable Monthly-IM 136) (microfilmed computer tabulation, 1972 data). According to this tabulation and "United States Imports from Japan, By Customs District of Entry, 1972" (United States-Japan Trade Council, no date; processed), the New York and Los Angeles port districts each accounted for 22 percent of U.S. imports from Japan. The third largest port, Seattle, Washington, accounted for only 6 percent, with the remaining 50 percent of U.S. imports from Japan distributed among all the rest. Besides the calculators mentioned in the text, air shipment accounted for 10 percent or more of imports of the TSUSA products noted in Table 3 for only two items, synthetic fabrics and radios, for each of which the proportion is 10 percent. Of all U.S. imports from Japan, 93 percent come by vessel and 6 percent by air.

Air transport is significant for only two items among U.S. imports from West Germany: textile knitting machinery ( 85 percent) and textile machinery parts (41 percent). Of total U.S. imports from West Germany, 84 percent come by vessel, 13 percent by air, and 3 percent were unaccounted for, according to U.S. Bureau of the Census, General Imports: World Area by Commodity Groupings, FT 155, 1972 Annual (1973), p. 266.

11. Jacques R. Artus, "The Short-Run Effects of Domestic Demand Pressure on Export Delivery Delays for Machinery," Journal of International Economics, Vol. 3 (February 1973), pp. 21-36. 
a pooling of the data for the total lag for 1971 and 1973. For all products except one, engines from Germany, the measure of skewness is positive indicating that the frequency distributions of the currency-contract period are skewed to the right.

\section{The Effects of Changes in Exchange Rates in the Currency-Contract Period}

\section{ASSUMPTIONS}

The calculations reported in this paper deal with the balance-of-trade effects of changes in exchange rates. The statistics on the balance of trade record the price and value of trade when the goods physically cross the national boundaries of the countries in question, and not when the goods are paid for. The timing of payment is affected by the financing of trade, both domestically and through international short-term capital movements; historical payment patterns; and the behavior of foreign exchange markets, among other factors. Payment thus can come before, at the time, or after goods move. The leads and lags of payments relative to movements of goods present a difficult empirical question, particularly at the time of a devaluation. In an effort to avoid capital losses when devaluation of the dollar is anticipated, U.S. importers whose contracts are denominated in foreign currency, and who have not hedged, speed their payments; and foreign exporters to the United States whose contracts are denominated in dollars will request early payment. ${ }^{12}$

In this paper I sidestep these questions and address explicitly only the effects of changes in foreign exchange rates on the reported trade statistics in the currency-contract period. The interactions of trade, payments, and other components of the balance of payments, such as short-term capital flows, are beyond the scope of this paper.

In the calculations performed in this section, I have made these assumptions:

1. Following the balance-of-payments conventions of most developed countries, exports are valued at the time the goods leave the exporting country and imports at the time they enter the importing country.

2. Changes in spot exchange rates are unanticipated.

12. See Bent Hansen, Foreign Trade Credits and Exchange Reserves (Amsterdam: North-Holland, 1196), and Grassman, Exchange Reserves, on the leads and lags problem. 
3. Contracts outstanding at the time of devaluation are not renegotiated.

4. Contracts outstanding at the time of devaluation are not canceled by either party before the goods are shipped.

5. The information from the documents of the U.S. Bureau of Customs used in this study correctly reflects the currency denomination and the length of contracts; these variables do not change through time.

In the last part of this section, I will comment on the biases introduced by each of these assumptions and speculate on behavior in financial markets, such as the extent to which the party taking the foreign exchange risk (that is, the party whose contracts are not denominated in its own currency) hedges, either in forward markets or otherwise.

\section{THE EFFECTS OF A SINGLE DEVALUATION OF THE DOLLAR}

An important distinction is developed in this section between the currency-contract period that is relevant for U.S. importers and the period that is relevant for foreign exporters of the same good to the United States. The length of the importer's currency-contract period equals the sum of the three lags discussed in the third section: the production lag, the transportation lag, and the entry lag. The exporter's currency-contract period is shorter, and equals only the time between order and export. Consider first the importer's currency-contract period.

A necessary first step in calculating the effect of a devaluation of the dollar on the price and value of U.S. imports is to determine the frequency distributions of the lengths of contracts that are in dollars and in foreign currency. A devaluation of the dollar in January, for example, will cause the dollar price of all imports denominated in foreign currency to rise in January. In February, all imports contracted in foreign currency will increase in dollars except that proportion of contracts with a length of one month or less-that is, those contracted after the devaluation. Thus, the frequency distributions of contract lengths provide the information needed to calculate the time profile of the currency-contract effect of devaluation on import prices and values.

Table 5 gives frequency distributions and cumulative distributions for the importer's currency-contract period by currency for U.S. imports from Japan and Germany based on a pooling of the 1971 and 1973 data, in order to get the maximum possible number of observations. ${ }^{13}$ The num-

13. The shape of the frequency distributions changed little from 1971 to 1973 for all imports (that is, all currency denominations). 
Table 5. Frequency and Cumulative Distributions of the Length of the Importer's Currency-Contract Period for U.S. Imports from Japan and West Germany, by Currency of Contract, Based on a Combined Sample for Fiscal Years 1971 and 1973

Percent of total trade

\begin{tabular}{|c|c|c|c|c|c|c|}
\hline \multirow{2}{*}{$\begin{array}{l}\text { Number } \\
\text { of } \\
\text { months }\end{array}$} & \multicolumn{3}{|c|}{ Japan } & \multicolumn{3}{|c|}{ West Germany } \\
\hline & Yen & Dollars & Total & $\begin{array}{c}\text { Deutsche } \\
\text { marks }\end{array}$ & Dollars & Total \\
\hline \multicolumn{7}{|c|}{ Frequency distribution } \\
\hline 1 & 2.6 & 2.6 & 5.2 & 32.2 & 0.3 & 32.5 \\
\hline 2 & 5.8 & 5.0 & 10.8 & 14.9 & 2.4 & 17.6 \\
\hline 3 & 7.4 & 11.1 & 18.5 & 9.6 & 3.8 & 17.8 \\
\hline 4 & 5.0 & 13.3 & 18.3 & 5.3 & 1.7 & 7.0 \\
\hline 5 & 3.4 & 8.4 & 11.9 & 3.2 & 1.7 & 5.0 \\
\hline 6 & 5.6 & 9.5 & 15.1 & 3.7 & 3.2 & 6.8 \\
\hline 7 & 2.3 & 1.5 & 3.8 & 3.6 & 0.8 & 4.4 \\
\hline 8 & 2.6 & 4.3 & 6.9 & 1.7 & 1.6 & 3.3 \\
\hline 9 & 0.2 & 1.4 & 1.6 & 0.0 & 0.5 & 0.5 \\
\hline 10 & 0.2 & 0.4 & 0.6 & 0.0 & 0.1 & 0.1 \\
\hline 11 & $0 . \overline{2}$ & 3.2 & 3.4 & 0.9 & 0.0 & 0.9 \\
\hline 12 & 1.0 & 0.4 & 1.5 & 0.2 & 0.1 & 0.3 \\
\hline 13 & 0.0 & 0.0 & 0.0 & 1.5 & 0.0 & 1.5 \\
\hline 14 & 0.1 & 0.3 & 0.4 & 0.3 & 0.4 & 0.6 \\
\hline 15 & 0.1 & 0.0 & 0.1 & 0.0 & 0.3 & 0.3 \\
\hline 16 & 0.0 & 0.5 & 0.5 & 0.0 & 0.0 & 0.0 \\
\hline 17 & 0.0 & 1.0 & 1.0 & 0.1 & 0.0 & 0.1 \\
\hline 18 & 0.0 & 0.1 & 0.1 & 0.0 & 0.0 & 0.0 \\
\hline 19 & 0.0 & 0.0 & 0.0 & 1.6 & 0.0 & 1.6 \\
\hline 20 & 0.0 & 0.0 & 0.0 & 0.0 & 0.0 & 0.0 \\
\hline 21 & 0.0 & 0.0 & 0.0 & 0.0 & 0.0 & 0.0 \\
\hline 22 & 0.0 & 0.3 & 0.3 & 0.0 & 0.0 & 0.0 \\
\hline \multicolumn{7}{|c|}{ Cumulative distribution } \\
\hline 1 & 2.6 & 2.6 & 5.2 & 32.2 & 0.3 & 32.5 \\
\hline 2 & 8.4 & 7.6 & 16.1 & 47.1 & 2.7 & 50.1 \\
\hline 3 & 15.8 & 18.7 & 34.6 & 56.7 & 6.5 & 67.8 \\
\hline 4 & 20.8 & 32.0 & 52.9 & 62.0 & 8.2 & 74.8 \\
\hline 5 & 24.2 & 40.4 & 64.7 & 65.2 & 9.9 & 79.7 \\
\hline 6 & 29.8 & 50.0 & 79.8 & 68.9 & 13.0 & 86.5 \\
\hline 7 & 32.1 & 51.5 & 83.6 & 72.4 & 13.8 & 90.9 \\
\hline 8 & 34.6 & 55.8 & 90.5 & 74.1 & 15.4 & 94.2 \\
\hline 9 & 34.9 & 57.1 & 92.1 & 74.1 & 15.9 & 94.7 \\
\hline 10 & 35.1 & 57.5 & 92.7 & 74.1 & 16.0 & 94.8 \\
\hline 11 & 35.3 & 60.7 & 96.1 & 75.0 & 16.0 & 95.6 \\
\hline 12 & 36.4 & 61.1 & 97.5 & 75.1 & 16.1 & 95.9 \\
\hline 13 & 36.4 & 61.1 & 97.5 & 76.6 & 16.1 & 97.4 \\
\hline 14 & 36.4 & 61.4 & 97.9 & 76.9 & 16.4 & 98.0 \\
\hline 15 & 36.6 & 61.4 & 98.0 & 76.9 & 16.7 & 98.3 \\
\hline 16 & 36.6 & 61.9 & 98.5 & 76.9 & 16.7 & 98.3 \\
\hline 17 & 36.6 & 62.9 & 99.6 & 77.0 & 16.7 & 98.4 \\
\hline 18 & 36.6 & 63.0 & 99.6 & 77.0 & 16.7 & 98.4 \\
\hline 19 & 36.6 & 63.0 & 99.6 & 78.6 & 16.7 & 100.0 \\
\hline 20 & 36.6 & 63.0 & 99.6 & 78.6 & 16.7 & 100.0 \\
\hline 21 & 36.6 & 63.0 & 99.6 & 78.6 & 16.7 & 100.0 \\
\hline 22 & 36.6 & 63.0 & 100.0 & 78.6 & 16.7 & 100.0 \\
\hline
\end{tabular}

Source: Same as Table 2. Details may not add to totals because of contracts in other currencies as well as rounding. 
bers in the top half of the table are the percentages of U.S. imports whose currency-contract period equals the given number of months. For example, of all U.S. imports from Japan, the fraction that was denominated in dollars and entered within the second month after order was 5.0 percent.

Since the overall frequency distribution is simply a weighted average of the individual product frequencies, ${ }^{14}$ the numbers in Table 5 were calculated by weighting each of the invoices reported in Table $2 .{ }^{15}$ Since some products were overrepresented and others underrepresented, the following weighting procedure was employed. First, I calculated the true share for product $j, t_{j}$, based on 1971 trade, from columns (3) and (4) of Table 1, with $\Sigma t_{j}=1$. Second, I calculated the share of product $j$ in the invoice sample, $s_{j}\left(\Sigma s_{j}=1\right)$, and then weighted each invoice for product $j$ by $w_{j}=t_{j} / s_{j}$. The sum of the $w_{j}$ s for all invoices equals 1 . Next, I calculated the frequency distribution, $f$, for the length of the currency-contract period by determining the percentage of U.S. imports from the country denominated in dollars, the exporter's currency, or other currencies, with the intervals stated in months. Finally, I calculated cumulative distributions from the frequencies. If $F_{i}$ is the percent of imports whose contract length is $i$ months or less and $F$ is the cumulative distribution for imports of all lengths (in effect, $F_{\infty}$ ), then, for U.S. imports from Germany, for example,

$$
F^{\$}+F^{D M}+F^{\circ}=100 \%
$$

where the superscripts indicate dollars, deutsche marks, and other currencies, respectively.

Figure 3 shows the frequency distributions by currency for the importer's currency-contract period for imports from Japan and Germany. One noteworthy feature is the discontinuity in the distribution of dollar contracts for imports from Japan: there is a bunching of contract lengths for several products in the fourth andsixth months; the peak in the eighth month is partly due to skewness in the product distributions. The other interesting result is the nearly monotonic decline in the distribution of deutsche mark contracts.

14. See Paul G. Hoel, Introduction to Mathematical Statistics (4th ed., John Wiley, 1971), p. 297.

15. Owing to omission of dates on some of the entries, the number of invoices used to determine the length of the currency-contract period was 14 percent below the number of invoices shown in Table 2 for Japan and 14 percent below that for Germany. 
Figure 3. Frequency Distributions of the Length of the Importer's Currency-Contract Period for U.S. Imports from Japan and West Germany, by Currency of Contract, Combined Fiscal Years 1971 and 1973

Percent of U.S. imports from the country

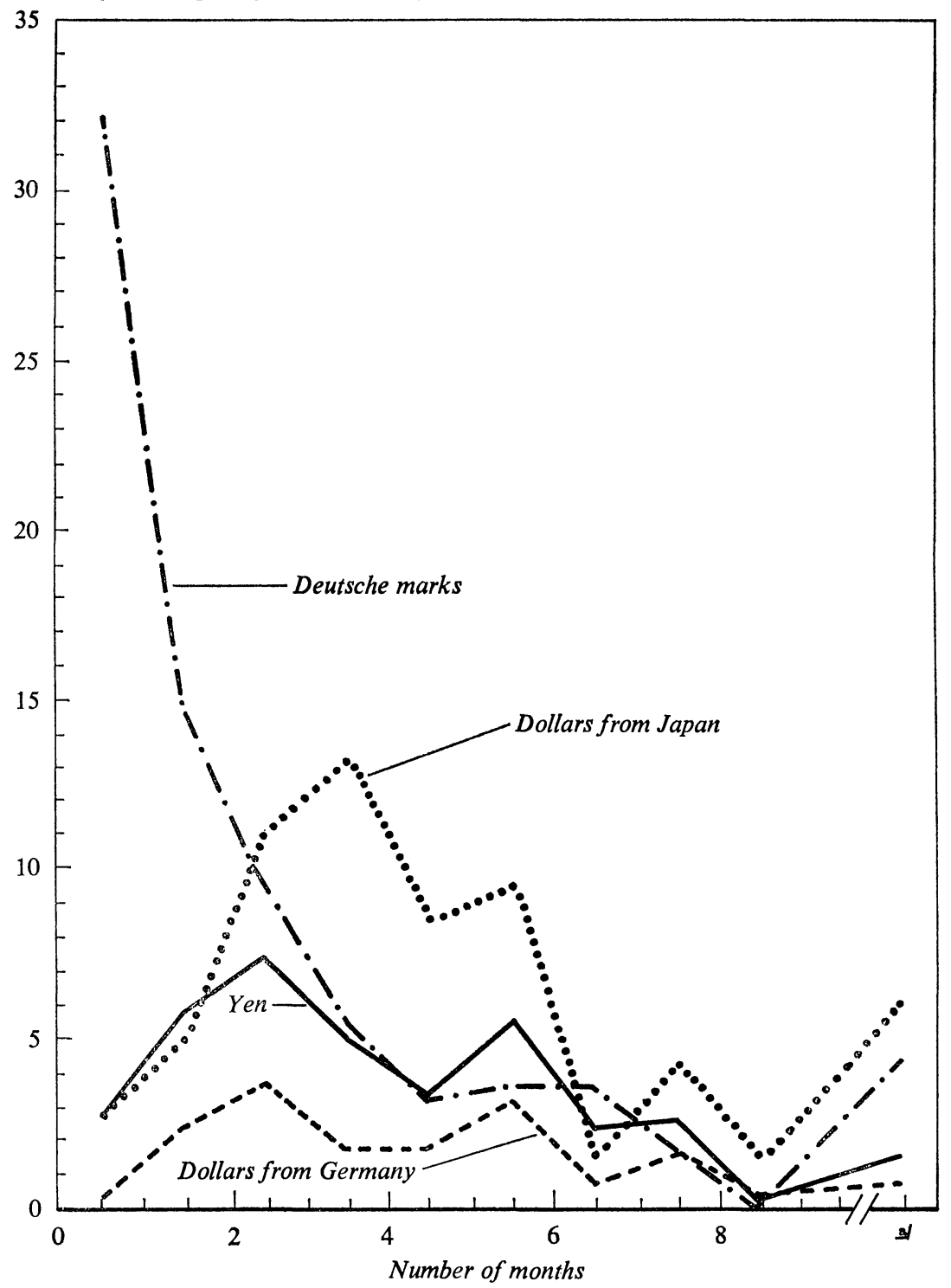

Source: Table 5.

a. This plot represents the sum of the data for months 10-22. 
The short lag on U.S. imports of German autos, together with the importance of this category, explains the large number of imports entering in the first and second months.

Given these distributions, the effects of changes in exchange rates on the prices and values of U.S. imports can be calculated. Assume that the dollar is devalued by $k$ percent at the beginning of month 1 . What happens to the price of U.S. imports in dollars, $P^{\$}$ ? Consider contracts in foreign currency, say, yen. In the month of devaluation, the dollar value of imports and import prices increase by the percentage increase in the dollar cost of foreign currency, $k$, times the cumulative frequency distribution for foreign currency contracts $(f c)$ of all lag lengths, $F^{f c}$. (Since, from Table 5, 37 percent of U.S. imports from Japan are denominated in yen, $F^{f c}=0.37$ ). At the beginning of the second month, some of the yen-denominated imports (specifically, $f^{f c}$ ) have been contracted after the devaluation, and thus are not relevant to the currency-contract period. (Their prices will be set by maximizing behavior, institutional arrangements, and so on, in the passthrough period.) Thus, in month 2 the frequency of all contracts with length $2-1$ months, or 1 month, $f_{1}^{f c}$, must be subtracted from $F^{f c}$. In month 3 , all contracts with lengths of $3-1$ months or less, $f_{1}^{f c}+f_{2}^{f c}$, must be subtracted. Since this sum is simply the cumulative frequency distribution, $F_{2}^{f c}$, the general formula for the percentage increment, or markup $\left(\widehat{M}_{t}^{\Phi}\right)$, in dollar import prices (and values) in month $t$ following a $k$ percent devaluation in month 1 is

$$
\widehat{M}_{t}^{\$}=k\left(F^{f c}-F_{t-1}^{f c}\right) .
$$

A circumflex over a variable indicates a percentage change.

The effect of dollar devaluation on the prices received by foreign exporters depends only on the exporter's currency-contract period; that is, the lag between acceptance of order and export. After the good is exported, its value is fixed and reported in the trade statistics of the exporting country as of that date. Thus, calculating foreign price effects requires using the frequency and cumulative distributions for the production lag, or the exporter's currency-contract period: $g$ and $G$. These distributions, based on the pooled 1971 and 1973 data, are shown in Table 6. A $k$ percent devaluation of the dollar (an increase in the ratio between dollars and foreign currency) causes the foreign currency value of dollar contracts to change by $-100 k /(100+k)$ percent. Thus, the percentage effect on the price and the value of dollar-denominated exports to the United States equals 
Table 6. Frequency and Cumulative Distributions of the Length of the Exporter's Currency-Contract Period for Japanese and West German Exporters to the United States, by Currency of Contract, Based on a Combined Sample for Fiscal Years 1971 and 1973

Percent of total trade

\begin{tabular}{|c|c|c|c|c|c|c|}
\hline \multirow{2}{*}{$\begin{array}{c}\text { Number } \\
\text { of } \\
\text { months }\end{array}$} & \multicolumn{3}{|c|}{ Japan } & \multicolumn{3}{|c|}{ West Germany } \\
\hline & Yen & Dollars & Total & $\begin{array}{c}\text { Deutsche } \\
\text { marks }\end{array}$ & Dollars & Total \\
\hline \multicolumn{7}{|c|}{ Frequency distribution } \\
\hline 1 & 7.2 & 6.9 & 14.1 & 46.9 & 1.6 & 51.7 \\
\hline 2 & 10.7 & 14.1 & 24.8 & 6.9 & 3.8 & 12.2 \\
\hline 3 & 3.1 & 18.8 & 21.9 & 6.5 & 2.1 & 8.6 \\
\hline 4 & 4.3 & 4.4 & 8.7 & 5.0 & 2.7 & 7.7 \\
\hline 5 & 6.2 & 6.7 & 13.0 & 0.9 & 3.0 & 4.0 \\
\hline 6 & 1.7 & 1.2 & 2.9 & 6.4 & 0.7 & 7.1 \\
\hline 7 & 1.7 & 3.4 & 5.1 & 0.0 & 2.0 & 2.0 \\
\hline 8 & 0.3 & 1.8 & 2.1 & 1.5 & 0.1 & 1.6 \\
\hline 9 & 0.2 & 3.5 & 3.8 & 0.0 & 0.1 & 0.1 \\
\hline 10 & 1.0 & 0.3 & 1.3 & 0.9 & 0.0 & 0.9 \\
\hline 11 & 0.0 & 0.2 & 0.2 & 0.2 & 0.1 & 0.3 \\
\hline 12 & 0.0 & 0.1 & 0.1 & 1.5 & 0.0 & 1.5 \\
\hline 13 & 0.0 & 0.2 & 0.2 & 0.0 & 0.4 & 0.4 \\
\hline 14 & 0.0 & 0.3 & 0.4 & 0.3 & 0.3 & 0.6 \\
\hline 15 & 0.1 & 0.0 & 0.1 & 0.0 & 0.0 & 0.0 \\
\hline 16 & 0.0 & 1.1 & 1.1 & 0.0 & 0.0 & 0.0 \\
\hline 17 & 0.0 & 0.0 & 0.0 & 0.1 & 0.0 & 0.1 \\
\hline 18 & 0.0 & 0.0 & 0.0 & 1.6 & 0.0 & 1.6 \\
\hline 19 & 0.0 & 0.0 & 0.0 & 0.0 & 0.0 & 0.0 \\
\hline 20 & 0.0 & 0.3 & 0.3 & 0.0 & 0.0 & 0.0 \\
\hline \multicolumn{7}{|c|}{ Cumulative distribution } \\
\hline 1 & 7.2 & 6.9 & 14.1 & 46.9 & 1.6 & 51.7 \\
\hline 2 & 17.9 & 21.0 & 38.9 & 53.8 & 5.4 & 63.9 \\
\hline 3 & 21.0 & 39.8 & 60.8 & 60.3 & 7.5 & 72.5 \\
\hline 4 & 25.2 & 44.2 & 69.5 & 65.3 & 10.1 & 80.1 \\
\hline 5 & 31.5 & 50.9 & 82.4 & 66.3 & 13.2 & 84.1 \\
\hline 6 & 33.2 & 52.1 & 85.3 & 72.6 & 13.8 & 91.2 \\
\hline 7 & 34.8 & 55.5 & 90.4 & 72.6 & 15.8 & 93.1 \\
\hline 8 & 35.1 & 57.3 & 92.5 & 74.1 & 15.9 & 94.7 \\
\hline 9 & 35.3 & 60.8 & 96.2 & 74.1 & 16.0 & 94.8 \\
\hline 10 & 36.4 & 61.1 & 97.5 & 75.0 & 16.0 & 95.6 \\
\hline 11 & 36.4 & 61.3 & 97.7 & 75.1 & 16.1 & 95.9 \\
\hline 12 & 36.4 & 61.4 & 97.8 & 76.6 & 16.1 & 97.4 \\
\hline 13 & 36.4 & 61.6 & 98.0 & 76.6 & 16.4 & 97.7 \\
\hline 14 & 36.4 & 61.9 & 98.4 & 76.9 & 16.7 & 98.3 \\
\hline 15 & 36.6 & 61.9 & 98.5 & 76.9 & 16.7 & 98.3 \\
\hline 16 & 36.6 & 63.0 & 99.6 & 76.9 & 16.7 & 98.3 \\
\hline 17 & 36.6 & 63.0 & 99.6 & 77.0 & 16.7 & 98.4 \\
\hline 18 & 36.6 & 63.0 & 99.6 & 78.6 & 16.7 & 100.0 \\
\hline 19 & 36.6 & 63.0 & 99.6 & 78.6 & 16.7 & 100.0 \\
\hline 20 & 36.6 & 63.3 & 100.0 & 78.6 & 16.7 & 100.0 \\
\hline
\end{tabular}

Source: Same as Table 2. Details may not add to totals because of contracts in other currencies as well as rounding. 


$$
\widehat{M}_{t}^{f c}=\frac{-100 k}{(100+k)}\left(G^{\$}-G_{t-1}^{\$}\right),
$$

where $G^{\$}$ is the cumulative distribution for the export currency-contract period for contracts denominated in dollars.

Table 7 shows the effects on U.S. import prices and values (from equation 1) and on foreign export prices and values (from equation 2) of a 10

\section{Table 7. Effects of a 10 Percent Devaluation of the Dollar in Month 1} on the Price of U.S. Imports in the Currency-Contract Period

Increment in prices of U.S. imports in percents

\begin{tabular}{|c|c|c|c|c|}
\hline \multirow{2}{*}{$\begin{array}{l}\text { Number } \\
\text { of } \\
\text { months }\end{array}$} & \multicolumn{2}{|c|}{ Japan } & \multicolumn{2}{|c|}{ West Germany } \\
\hline & Dollars & Yen & Dollars & Deutsche marks \\
\hline 1 & 3.7 & -5.8 & 7.9 & -1.5 \\
\hline 2 & 3.4 & -5.1 & 4.6 & -1.4 \\
\hline 3 & 2.8 & -3.9 & 3.2 & -1.0 \\
\hline 4 & 2.1 & -2.1 & 2.2 & -0.8 \\
\hline 5 & 1.6 & -1.7 & 1.7 & -0.6 \\
\hline 6 & 1.2 & -1.1 & 1.3 & -0.3 \\
\hline 7 & 0.7 & -1.0 & 1.0 & -0.3 \\
\hline 8 & 0.5 & -0.7 & 0.6 & -0.1 \\
\hline 9 & 0.2 & -0.5 & 0.5 & -0.1 \\
\hline 10 & 0.2 & -0.2 & 0.5 & -0.1 \\
\hline 11 & 0.1 & -0.2 & 0.5 & -0.1 \\
\hline 12 & 0.1 & -0.2 & 0.4 & -0.1 \\
\hline 13 & 0.0 & -0.2 & 0.3 & -0.1 \\
\hline 14 & 0.0 & -0.2 & 0.2 & 0.0 \\
\hline 15 & 0.0 & -0.1 & 0.2 & 0.0 \\
\hline 16 & 0.0 & -0.1 & 0.2 & 0.0 \\
\hline 17 & 0.0 & 0.0 & 0.2 & 0.0 \\
\hline 18 & 0.0 & 0.0 & 0.2 & 0.0 \\
\hline 19 & 0.0 & 0.0 & 0.2 & 0.0 \\
\hline 20 & 0.0 & 0.0 & 0.0 & 0.0 \\
\hline 21 & 0.0 & 0.0 & 0.0 & 0.0 \\
\hline 22 & 0.0 & 0.0 & 0.0 & 0.0 \\
\hline
\end{tabular}

Sources: Derived from the proportional distributions in Tables 5 and 6, and text equations (1) and (2). a. This is the change in each month relative to the level that would have obtained in the absence of devaluation, not the change from the preceding month. This table reports the effects of the devaluation based on the stock of outstanding contracts at the beginning of each month. The currency-contract effect on average prices throughout the entire month depends on the average stock of outstanding contracts during the month. Since most contracts falling due within one month have lengths just below 30 days, the first-of-the-month stock is a good approximation for the first month's average. However, after month 1, a reasonable approximation of the average monthly price effect can be obtained by averaging the beginning and end-of-month stocks of outstanding contracts. 
percent devaluation of the dollar. Notice the monotonic decline to zero in the absolute price effect during the currency-contract period. In the long run, there is no currency-contract effect: by twenty-two months after the devaluation, all contracts have lapsed for imports from Japan, and by nineteen months, all contracts have lapsed for imports from Germany.

A more important point is that given the assumptions and a once-andfor-all devaluation, the currency-contract period can contribute to the downward slope of the J-curve effect on imports only in the first month following devaluation. Thereafter, the curve rises toward zero. Figure 4 shows the increase in the value and price of U.S. imports in the currencycontract period and the contribution of the latter, with a negative sign, to the J-curve. The depth of the drop in the import J-curves is determined by the proportion of contracts denominated in foreign currency: it is relatively larger for imports from Germany. Finally, the upward part of these import J-curves is generally concave from below rather than convex. A $\gamma$-curve might better reflect the currency-contract contribution of imports to the J-curve. ${ }^{16}$ The reader is warned, however, that these results depend on the assumptions listed at the outset. One of the most restrictive for this discussion of the empirical effects is that the devaluation is unanticipated.

\section{CONTINUOUS CHANGES IN EXCHANGE RATES}

What is the effect of continuous changes in exchange rates on import prices and values? In view of the many changes in exchange rates since 1971, the impact of currency contracts on import prices and values by month is of special empirical interest. For this analysis, the frequency distributions rather than the cumulative distributions are required.

Consider imports in any month, $t$. In that month, the proportion $f_{1}$ enters under contracts negotiated in the previous month, $f_{2}$ under contracts negotiated two months before, and so on, extending back empirically for a maximum of twenty-two months (see Table 5). The currency-contract markup in the dollar price of imports denominated in foreign currency for contracts made $i$ months ago is the percentage change in the exchange rate

16. See Magee, "Currency Contracts," p. 322, for the letters of the Roman alphabet that could be used to describe the behavior of the trade balance following devaluation. Terrence Thomas, in correspondence, has suggested that the postdevaluation trade balance might trace out "Harry Johnson," given enough assumiptions. 


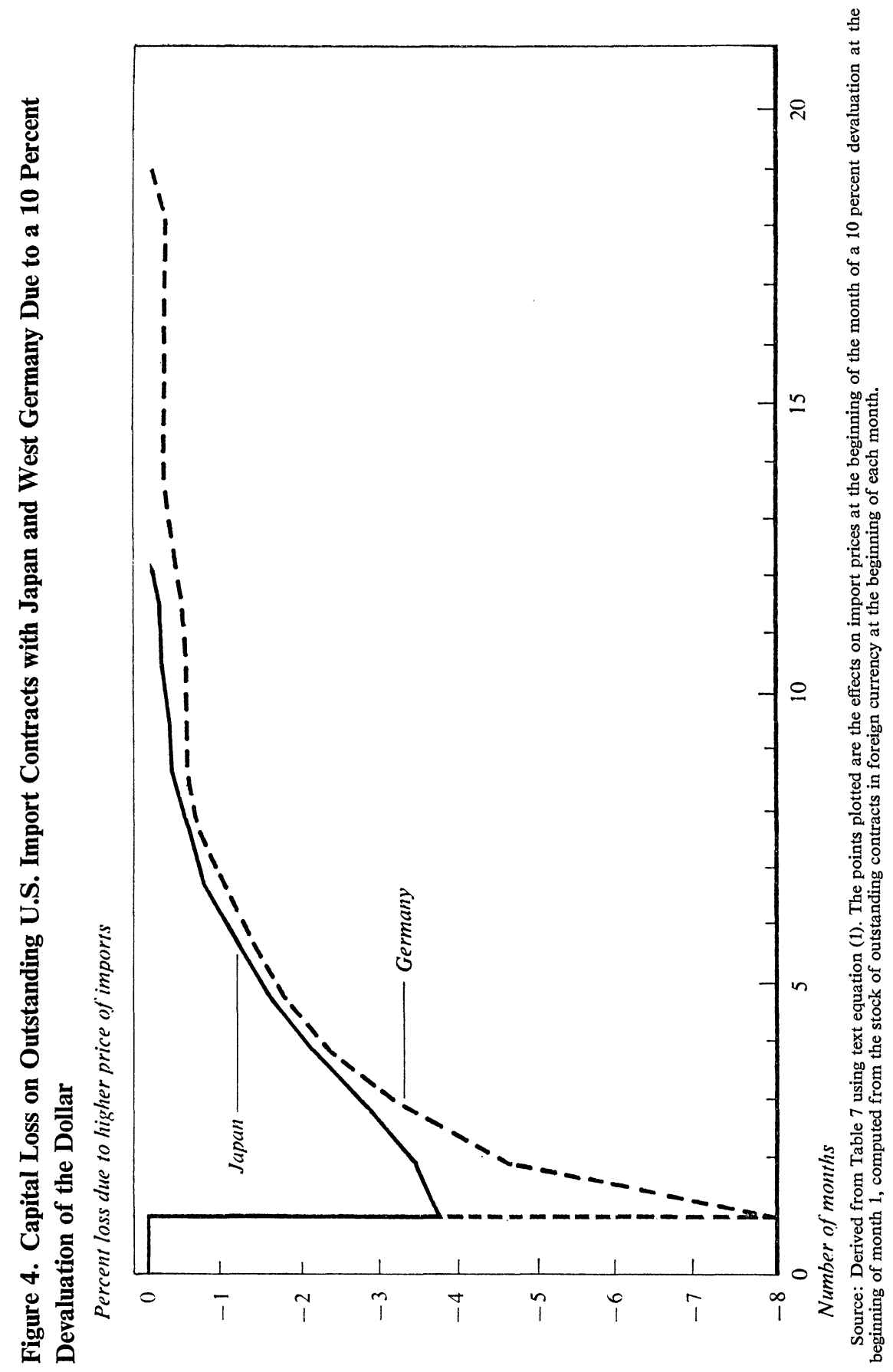


from period $t-i$ to period $t$. Thus, the percentage change for any month $t$ in the dollar price (and value) of imports $\left(\widehat{M}_{t}^{\$}\right)$ due to the impact of exchange rate changes during the relevant past period on outstanding contracts denominated in foreign currencies is

$$
\widehat{M}_{t}^{\Phi}=\sum_{i=1}^{22} f_{i}^{f c} \widehat{F X}_{i-i}^{t},
$$

where $\widehat{F X}_{t-i}^{t}$ is the percentage change in the dollar cost of foreign currency from $t-i$ to $t$, and $f_{i}^{f c}$ is the proportional frequency distribution of the importer's currency-contract period. The percentage change at time $t$ in the price of U.S. imports expressed in foreign currency for contracts denominated in dollars is

$$
\widehat{M}_{t}^{f c}=\sum_{i=1}^{22} g_{i}^{\$} \widehat{F X}_{t}^{t-i},
$$

where $g_{i}^{\$}$ is the proportional frequency distribution for the exporter's currency-contract period shown in Table $6 .{ }^{17}$

These increments in the prices and values of U.S. imports from Japan and Germany, and the relevant exchange rates (January $1971=100$ ), are shown in Table 8. The numbers in the table are simulations of the changes in the prices and values due to currency-contract effects using actual exchange rate changes since January 1971 in equations (3) and (4). Notice the relatively large declines in Japanese export prices in yen in the following quarters-1971:4, 1972:1, 1973:1, and 1973:2. The frequency distribution for Germany is heavily weighted in the first and second months, so that large changes in the value of the deutsche mark were translated quickly into increased U.S. import prices. The deutsche mark rose relatively gradually in 1971; however, its rapid rise in 1973 caused the value of German imports to be marked up in the first three quarters of 1973 by $4.67,6.45$, and 8.89 percent, respectively.

\section{RELAXING THE ASSUMPTIONS}

The calculations in this section were based on several assumptions, listed at the start of the section. Does the unreality of these assumptions lead to overestimates or underestimates of the currency-contract effects?

17. For dollar devaluation, since $\widehat{F X}_{t-i}^{t}$ is the percentage increase in the dollar cost of foreign currency, $\widehat{F X}_{t}^{t-i}$ is the percentage decrease in the foreign currency cost of dollars. 


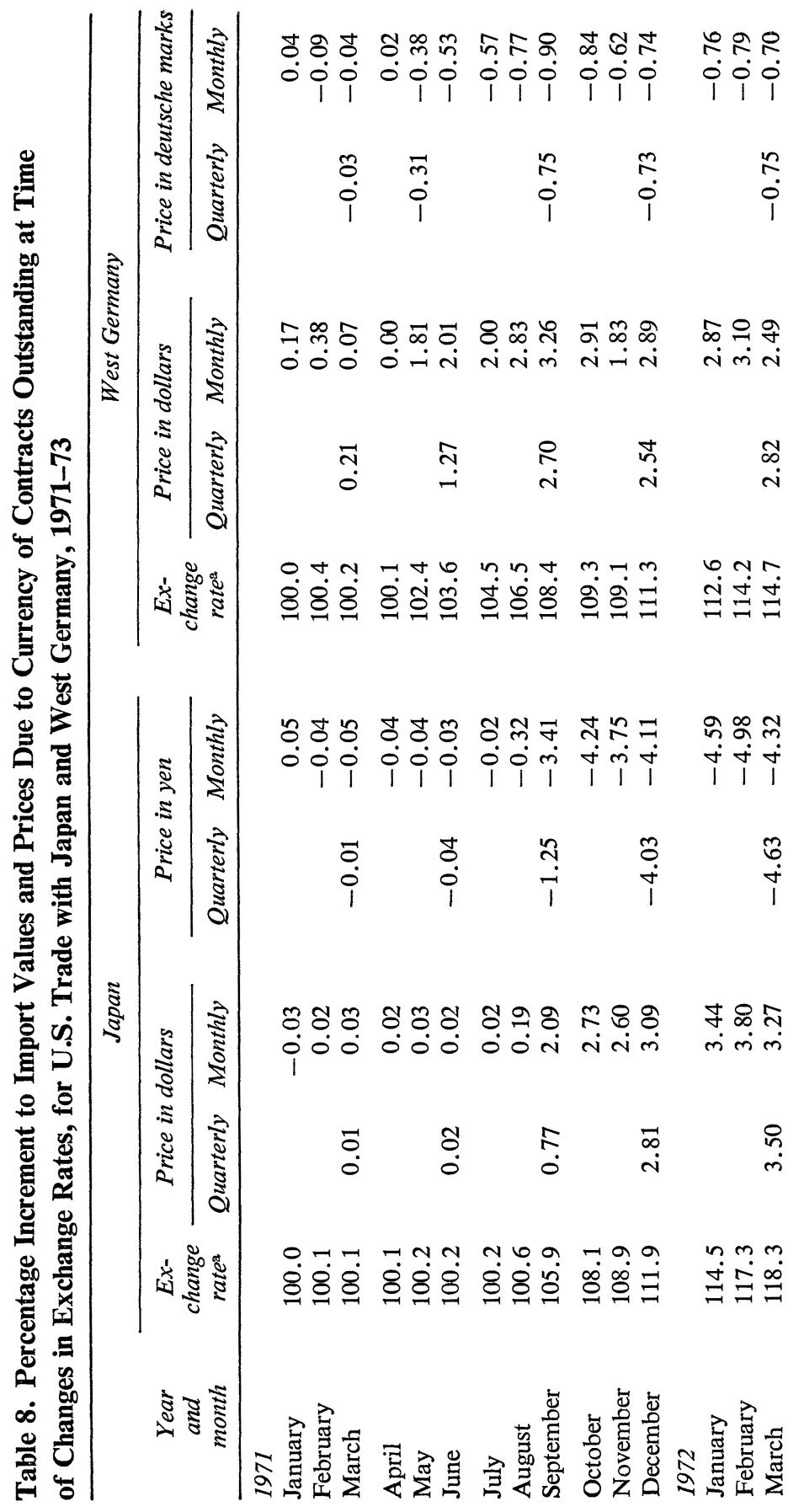




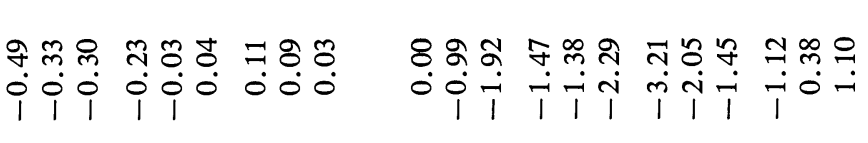

$\begin{array}{lll}\hat{m} & 0 & 0 \\ 0 & 0 & 0\end{array}$

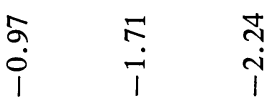

$\stackrel{\sim}{\mathfrak{0}}$

苋

กำร -

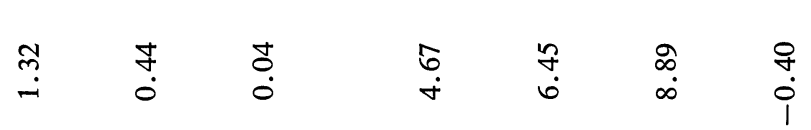

$\forall+\infty$ or thN

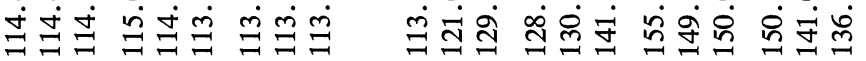

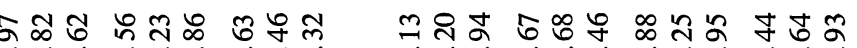

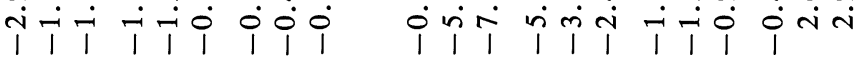
$\stackrel{i}{\stackrel{1}{*}} \quad \stackrel{i}{~}$

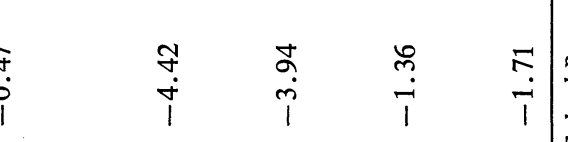


Consider assumptions 3 and 4, that contracts are neither renegotiated nor canceled. Since most imports from Japan are in dollars, Japanese exporters, in an effort to avoid capital losses in the currency-contract period, may renegotiate contracts, which will raise both the yen and the dollar price, or cancel the contracts, which will decrease the proportion of contracts denominated in dollars. Both of these phenomena imply that the calculations in Tables 7 and 8 understate the increase in the dollar cost of imports from Japan, and overstate the decrease in their yen value, during a period of dollar devaluation. The situation is reversed for imports from Germany. Since most contracts are in deutsche marks, the greater likelihood is that U.S. importers will renegotiate in order to hold down the increase in dollar price, or will cancel, reducing the overall proportion of contracts in deutsche marks. To the extent that these tendencies operate, the increase in the dollar cost of imports from Germany is overstated in the tables and the fall in the deutsche mark price of German exports to the United States is understated.

Assumption 5 is that the distribution of the lengths of the contracts does not change through time. However, devaluation itself is likely to alter the distribution. As an illustration, consider a devaluation of the dollar on January 1 and calculate the currency-contract effect on, say, April imports. For items with short contracts-specifically, those goods contracted since January 1 that will enter the United States in April-the adjustment process becomes relevant. If demand for these items is price elastic or if the monetary adjustment process has forced these imports to shrink, then the share of short contracts in April's imports will drop and the share of longer contracts (those entered into before devaluation) will rise. Using the historical distributions causes an underestimate of the true share of April's imports that were contracted before January 1 and an underestimate of the markup in the dollar price of imports induced by the devaluation (the reverse is true for short contracts with inelastic demand).

Assumption 1 is violated by the U.S. practice of measuring imports at the time of exportation. The effects of this practice will be measured in the next section.

A final word on anticipations and hedging. If the change in the exchange rate is anticipated all at once, say, two months before it actually occurs, the currency-contract effects are shifted backward in time. For example, when the foreign exporter takes his dollar-denominated contract and bill of lading to his bank for discounting, the discount will be affected by the 
market's expectation about the future value of the dollar. Thus, if the forward rates are an unbiased estimate of future spot rates, the gap between the forward and realized future spot rates might be a better measure of unfulfilled expectations.

Given the tendency toward dollar-denominated Japanese exports to the United States and deutsche mark-denominated German exports to the United States, the foreign exchange risk is normally taken by the Japanese exporter and by the U.S. importer from Germany. I have no hard evidence on the Japanese case, but am told that hedging by Japanese exporters was the exception rather than the rule in the 1971-73 period. Evidence from Fieleke indicates that about one-fourth of U.S. importers of German products hedge their exchange risk. ${ }^{18}$

\section{Errors in U.S. Import Statistics in the Currency-Contract Period}

The previous section reported calculations of the impact that the currency of contracts has on the prices and values of U.S. imports after a devaluation. Would these effects show up accurately in the U.S. import data? The answer is "maybe," at best, because valuation of imports is subject to at least three troublesome errors immediately following a change in exchange rates. ${ }^{19}$

18. Computed from Norman S. Fieleke, "The 1971 Flotation of the Mark and the Hedging of Commercial Transactions Between the United States and Germany: Experiences of Selected U.S. Non-Banking Enterprises," Journal of International Business Studies, Vol. 4 (Spring 1973), pp. 43-59. I computed the number in the text from Table 2, p. 53, in consultation with Fieleke.

19. These errors are apart from the usual list of "horror stories" about unit values. Such stories have been reported in The Balance of Payments Statistics of the United States: A Review and Appraisal, Report of the Review Committee for Balance of Payments Statistics to the Bureau of the Budget (U.S. Government Printing Office, 1965); Robert E. Lipsey, Price and Quantity Trends in the Foreign Trade of the United States (Princeton University Press for the National Bureau of Economic Research, 1963); G.C. Hufbauer and J. P. O'Neill, "Unit Values of U.S. Machinery Exports," Journal of International Economics, Vol. 2 (August 1972), pp. 265-75; and James I. Walsh, "On the Suitability of Aggregate Import Unit Value Indexes for Estimating Import Demand Elasticities" (Office of the Special Representative for Trade Negotiations, 1973; processed). The errors cited in these studies include errors in invoices, problems with timing, heterogeneity within product classes, differential valuation of imports subject to ad valorem duties, lack of comparability of unit-value indexes with other price indexes because of differences in coverage and weighting, and the small number of products used to construct certain component unit-value indexes. 
The largest single error in establishing the price and value of U.S. imports in the currency-contract period is the tendency of the Customs Bureau to ignore the currency of the contract in valuing the imports for duty purposes. Customs marks up the value of all imports subject to ad valorem duties from a country when the dollar cost of that country's currency rises, regardless of whether the contract is denominated in dollars or in foreign currency.

The second error arises from the regulation requiring the bureau to use a fixed exchange rate to value imports within each quarter if the rate remains within 5 percent of its value on the first day of the quarter.

The third error is the bureau's practice of valuing U.S. imports f.o.b. at the time of export; in effect, it uses the export rather than the import currency-contract period in valuing imports. (Canada is another major country that values its imports on this basis.) If the dollar is devalued after a product is shipped to the United States but before it arrives, no adjustment is made for the change in its dollar valuation at the time of entry.

While the third point might be considered more a convention than an error, the first two, the currency-contract error and the error deriving from the 5 percent rule, have not yet been explored. In the final part of this section, I shall provide an estimate of the importance of each of these three errors in the 1971-73 period. $^{20}$

\section{THE CURRENCY-CONTRACT ERROR}

If the officially used rate of conversion changes between the time a good is contracted for export and the time it is exported, the value of the invoice for customs purposes is changed by the percentage change in the dollar value of foreign currency for all goods subject to ad valorem duties, regardless of whether the invoice is contracted for in dollars or in foreign currency. For contracts denominated in foreign currency, this practice makes economic sense since the U.S. importer must pay a higher price if the dollar weakens (that is, if the dollar price of foreign currency rises). However, it makes no sense for U.S. imports contracted in dollars, since the foreigner absorbs any economic loss. Thus, the value of all U.S. imports denominated

20. Some, but not all, of these errors will be absent from the new c.i.f. import values reported by the Bureau of the Census starting in January 1974. See U.S. Bureau of the Census, Summary of U.S. Export and Import Merchandise Trade: January 1974, FT 900-74-1 (February 27, 1974), p. 1. 
in dollars subject to ad valorem duties is overstated by the percentage change in the official conversion rates between the time of contract and export.

This rule and exceptions to it are outlined in a telegram sent on December 30, 1971, from the Acting Commissioner of Customs to all Regional Commissioners. ${ }^{21}$ The telegram stated that the value and the price of all U.S. imports covered by contracts in dollars would be marked up by the increased dollar cost of the foreign currency unless the importer could prove that the foreign price fell from the contract date to the export date.

This error arises because, in pursuing essentially conflicting goals, the Customs Bureau feels that its statistical responsibilities are secondary to its obligation to "safeguard" revenue. This ranking is reflected in a 1972 decision by the Customs Bureau that, whenever the certified exchange rate was altered between the time the contract was entered into and the date the goods were exported, the bureau had the "duty of protecting the revenue," and would mark up contracts whenever there was "insufficient information as to market value" of the goods on the export date. ${ }^{22}$ Thus, a weakening of the dollar through devaluation would mean an upward bias in valuation of imports. ${ }^{23}$ Again, the importer was given the opportunity to present any mitigating evidence.

The proportion of imports subject to this rigorous test in the 1971-73 period is uncertain. My best judgment is that this practice has caused at least a moderate overstatement of the value of imports denominated in dollars. First, importers did not always have sufficient incentive to resist it. If the duty on an imported good was very low, the marginal cost from proving that the foreign currency price had fallen would (except on large orders) be more than the increment in duty liabilities resulting from the overstatement. Second, even if the importer can establish that he had a dollar-denominated contract, customs officers, in the effort to maximize revenue, are authorized to challenge it, using contracts of similar goods from the same

21. Telegram addressed "To All Regional Commissioners of Customs" from Edwin F. Rains, Acting Commissioner of Customs, December 30, 1971.

22. Circular from Customs Information Exchange, U.S. Customhouse, Re: Section 27.37 C.M., C.I.E. N290/72, July 3, 1972.

23. However, the decision was not symmetrical in that the bureau would not mark down dollar contracts when the dollar was appreciating: in this situation they would use "values in the higher part of the possible range of values." Thus, if the dollar were appreciating no error would arise because the dollar value of imports denominated in dollars would not be marked down. 
country denominated in foreign currency if they believe that the importer is understating value to avoid duties. Third, even when an importer obtains documentation after entry proving that the "freely offered price" of a good he purchased fell because of a dollar-denominated contract, and receives a refund on overpayment of duties, the correction of these invoices at the time of liquidation will almost never find its way into published data, unless the transaction is large.

The currency-contract error will be important for U.S. imports from countries such as Japan, whose exports to the United States are largely dollar-denominated and whose trade is largely subject to ad valorem duties (or mixed duties, which are a combination of specific and ad valorem rates). In addition to Japan (86 percent of whose U.S. trade is subject to ad valorem rates), such countries include the European Economic Community, excluding the United Kingdom (76 percent); the United Kingdom and Ireland (56 percent); and the rest of Western Europe (75 percent). At the other end of the scale are Canada (16 percent); Mexico (25 percent); Australia, New Zealand, and Oceania (12 percent); and Africa (9 percent). ${ }^{24}$

\section{THE CUSTOMS RATE OF EXCHANGE}

Customs Bureau regulations require that foreign prices at the time of exportation be converted into U.S. dollars at the "customs" rate of exchange prevailing on the day of exportation. ${ }^{25}$ The rate is established for each country on the first day of every quarter and is certified by the Federal Reserve Bank of New York. It is used to value U.S. imports throughout the entire quarter, so long as the dollar price of the foreign currency does not vary from it by 5 percent or more. The market rate is used for any day on which it falls outside that limit. If the market rate fluctuates outside, and then returns to within, 5 percent of the customs rate at the beginning of the quarter, the rate used to value imports returns to that customs rate.

24. Calculated from Customs Valuation, Report of the U.S. Tariff Commission to the Senate Committee on Finance and the Subcommittee on International Trade, 93 Cong. 1 sess. (U.S. Government Printing Office, 1973), p. 156; and U.S. Bureau of the Census, Highlights of U.S. Export and Import Trade, FT 990 (December 1970), Table I-4. Since the percentages in the text are based on data sources that are not strictly comparable, they are subject to some error.

25. "Customs Regulations of the United States," published in Custom House Guide, 1971 Edition (New York: Budd Publications, 1971), sec. 16.4(d), p. 1794. 
The customs and market foreign exchange rates for the yen from January through March 1974 are shown in Figure 5 (the dotted line indicates dates when the customs rate differed from the daily rate). Whenever the market rate deviated by 5 percent or more from the initial customs rate, the two lines coincide. February 1974 illustrates the variation exhibited by the rate used to value imports whenever the market rate oscillates around 5 percent of the customs rate. In general, the 5 percent rule causes a smoothing of fluctuations within quarters but discontinuities between quarters in the values and prices of imports in situations of floating exchange rates. While the rule is an understandable effort to simplify the administration of import valuation, it could lead to errors of 10 percent in the values of imports between quarters when exchange rates are changing.

\section{VALUATION OF IMPORTS AT THE TIME OF EXPORTATION}

The valuation of U.S. imports grows out of the Constitution and a set of laws beginning with the Tariff Act of $1930 .{ }^{26}$

U.S. imports are valued by the Bureau of Customs for duty in the foreign country, in line with the following two constitutional provisions:

The Congress shall have power to lay and collect taxes, duties, imposts and excises, to pay the debts and provide for the common defense and general welfare of the United States; but all duties, imposts and excises shall be uniform throughout the United States (Article I, Section 8, Clause 1; emphasis supplied).

No preference shall be given by any regulation of commerce or revenue to the ports of one State over those of another (Article I, Section 9, Clause 6; emphasis supplied).

The United States Supreme Court has ruled that the uniformity required by the Constitution is geographical, and thus has ruled out any c.i.f. scheme of duties in which the same product coming from the same foreign country would be valued differently by different states. Thus, the place of valuation is the foreign country of exportation and the time of valuation is the date of exportation. ${ }^{27}$

26. For historical and current custom procedures, see Customs Valuation; U.S. Bureau of the Census, Guide to Foreign Trade Statistics: 1972 (May 1972); U.S. Department of the Treasury, Customs Service, Exporting to the United States (1973); Custom House Guide, latest edition; and "Title 19-Customs Duties," United States Code, 1970 Edition, Vol. 5 (1971).

27. The complicated and bizarre legal definitions of valuation that are used in determining duty liabilities reduce the statistical reliability of the customs import data, particu- 


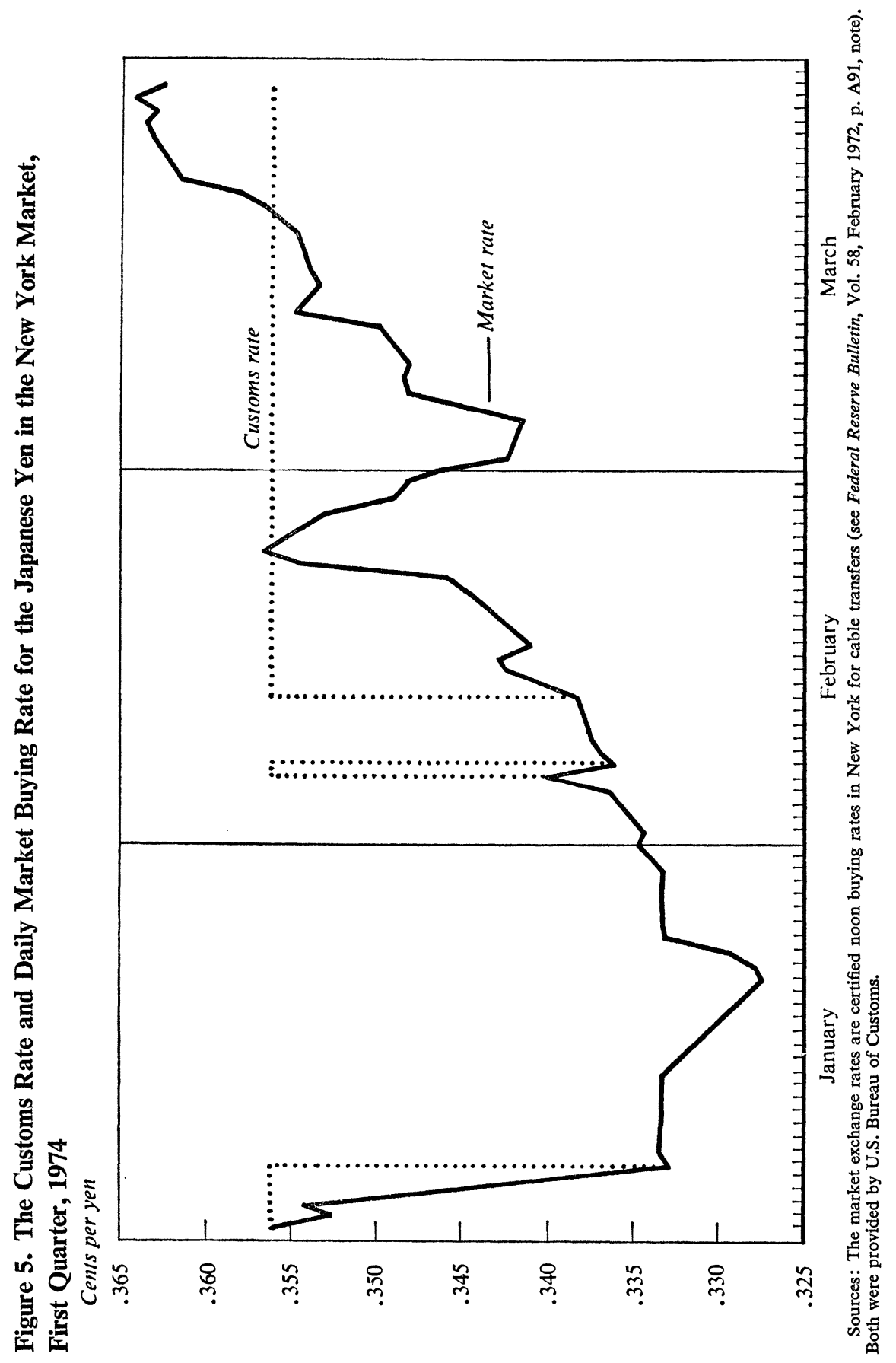


Because the United States does not value its imports at the time of importation (even under the new program), as most other countries do, the import statistics understated increases in imports in the currency-contract period due to devaluation of the dollar. The reason is that goods that are in transit to the United States or that have been imported but not entered, under foreign-currency contracts outstanding at the time of the devaluation, are not marked up by the change in the exchange rate.

\section{MEASUREMENT OF THE VALUATION ERRORS}

This section reports measurements by simulation of the three errors in the U.S. import statistics from January 1971 through December 1973 (using the actual changes in the market and the customs exchange rates). First, the practice of measuring U.S. imports at the time they leave the exporting country fails to capture that part of the currency-contract effect on imports denominated in foreign currency that is due to changes in exchange rates that occur during the transportation and entry periods.

Consider, after a dollar devaluation, imports into the United States in month $t$ that have an import currency-contract period of length $i$ and thus would have been contracted in month $t-i$. Because the Customs Bureau values imports denominated in foreign currency by the exchange rate at

larly at the time of a devaluation. For those U.S. imports (56 percent in 1970) that were either duty free or subject to specific duties only, valuation is generally believed to reflect the actual invoice or contract price. A breakdown for the 44 percent of imports subject to the compound or ad valorem tariff rates, using estimates based on 1969 data, shows that 35 percent are valued according to "export value"; 6 percent are valued by the "cost of production"; more than 2 percent each according to the "constructed value," the "American selling price," and the "U.S. value"; and less than 1 percent according to the "foreign value." Each of these valuation schemes has elaborate legal foundations (see Customs Valuation, pp. 67-71, for data and definitions).

The alternative schemes introduce unknown biases into the trade data because the composition of trade can shift between categories that use very different methods of valuation, and because devaluation may have different effects on value depending on the criteria under which the goods are valued.

Finally, the value of imports and their price are simultaneously determined, since the quantities on the invoices are fixed. Thus, all errors in valuation are transmitted directly into errors in the unit values. The only virtue is that deflating a value index for U.S. imports by the unit-value index should yield the true quantity measure (apart from the inadequacies in quantities listed in note 19 , such as product heterogeneity). 
the time the good was exported, it reflects changes only over the export currency-contract period (denoted by $j$ ). Customs valuation reflects only the movement in the exchange rate between month $t-i$ and $t-i+j$. The error caused by this practice depends on the proportions of trade denominated in foreign currency whose import contract length is $i$ and whose export contract length is $j$-that is,

$$
f_{i j}^{f c}
$$

Since lag $j$ is simply the first of three parts of lag $i, j \leq i$,

$$
f_{i}^{f c}=\sum_{j=1}^{i} f_{i j^{*}}^{f c}
$$

Thus, the measured effect of changes in exchange rates on imports denominated in foreign currency entering in month $t$, contracted $i$ months before (in month $t-i$ ) and exported $j$ months after contract, is

$$
f_{i j}^{f c} \widehat{F X}_{t-i}^{t-i+j} \text {. }
$$

For imports contracted in month $t-i$, summed over $j$, and entering in month $t$, the effect is

$$
\widehat{X}_{1}=\sum_{j=1}^{i} f_{i j}^{f_{c}} \widehat{F X}_{t-i}^{t-i+j} \text {. }
$$

Summed over all import contract lengths, $i$, this term gives the measured change in these imports, ${ }^{28}$

$$
\widehat{X}_{2}=\sum_{i=1}^{22} \sum_{j=1}^{i} f_{i j}^{f c} \widehat{F X}_{t-i}^{t-i+j}
$$

The actual change, however, reflects fully changes in exchange rates between $t-i$ and $t$ :

$$
\widehat{X}_{3}=\sum_{i=1}^{22} f_{i}^{f c} \widehat{F X}_{t-i}^{t}
$$

Thus, the percentage "time-of-export error" in month $t, \widehat{T E} E_{t}$, is the difference between $\widehat{X}_{2}$ and $\widehat{X}_{3}$ :

$$
\widehat{T E E_{t}}=\sum_{i=1}^{22}\left[\left(\sum_{j=1}^{i} f_{i j}^{f c} \widehat{F X}_{t-i}^{t-i+j}\right)-f_{i}^{f c} \widehat{F X}_{t-i}^{t}\right] .
$$

Next, what is the error caused by converting contracts denominated in foreign currency into dollars at the customs rather than the market ex-

28. This is not strictly the "measured" change since it refers to the market rather than the customs foreign exchange rate that is actually used. 
change rate? For unanticipated changes in exchange rates and nominal interest rates that are the same in the two countries, the relevant exchange rate for both parties at the time the contract is negotiated is $F X_{t-i}$. At the time of export, $j$ months later, the market rate is $F X_{t-i+j}$, but the customs rate used to value imports as of that date is $C R_{t-i+j}$. Thus, the percentage "customs-rate error," $\widehat{C R} E_{t}$, for imports entering the United States in month $t$, is

$$
\widehat{C R} E_{t}=\sum_{i=1}^{22} \sum_{j=1}^{i} f_{i j}^{f c}\left(\frac{C R_{t-i+\jmath}}{F X_{t-i}}-\frac{F X_{t-i+j}}{F X_{t-i}}\right) 100 .
$$

Finally, what is the effect of the Customs Bureau's practice of marking up dollar-denominated contracts by the increased dollar cost of foreign currency? This practice is followed consistently only on goods subject to some form of ad valorem duties. The percentage "currency-contract error" in month $t, \widehat{C C} E_{t}$, is equal to the proportion of goods subject to ad valorem rates, $v,{ }^{29}$ times the summed products of the frequency distributions and the changes in customs exchange rates between $t-i$ and $t-i+j$ :

$$
\widehat{C C} E_{t}=\sum_{i=1}^{22} \sum_{j=1}^{i} v f_{i j}^{\$} \max \left[\widehat{C R}_{t-i}^{t-i+j} ; 0\right] .
$$

(This error can cause only upward bias in the import statistics since customs marks up dollar-denominated contracts when the dollar cost of foreign exchange is rising but does not mark them down when it is falling.)

This error can be sizable for U.S. imports from countries such as Japan with large proportions of dollar-denominated contracts. There are two biases in the measurement of $\widehat{C C} E_{t}$, which fortunately are of opposite sign. $\widehat{C C} E_{t}$ is overstated to the extent that U.S. importers can convince customs officials that the markup is improper since the foreign currency price actually fell, as explained in detail in the previous section. The currency-contract error applies to dollar-denominated U.S. imports subject to ad valorem duties. However, to the extent that the dollar-denominated goods that are marked up are subject either to specific duties or to no tariffs at all (that is, goods closely monitored by customs, such as those suspected of dumping violations), the error is understated.

One desirable property of the errors measured here, at least for expository purposes, is that their sum, the total error, $\widehat{T E}_{t}$, equals by definition

29. For Japan, $v=0.86$ and for Germany, $v=0.76$, as noted above. 


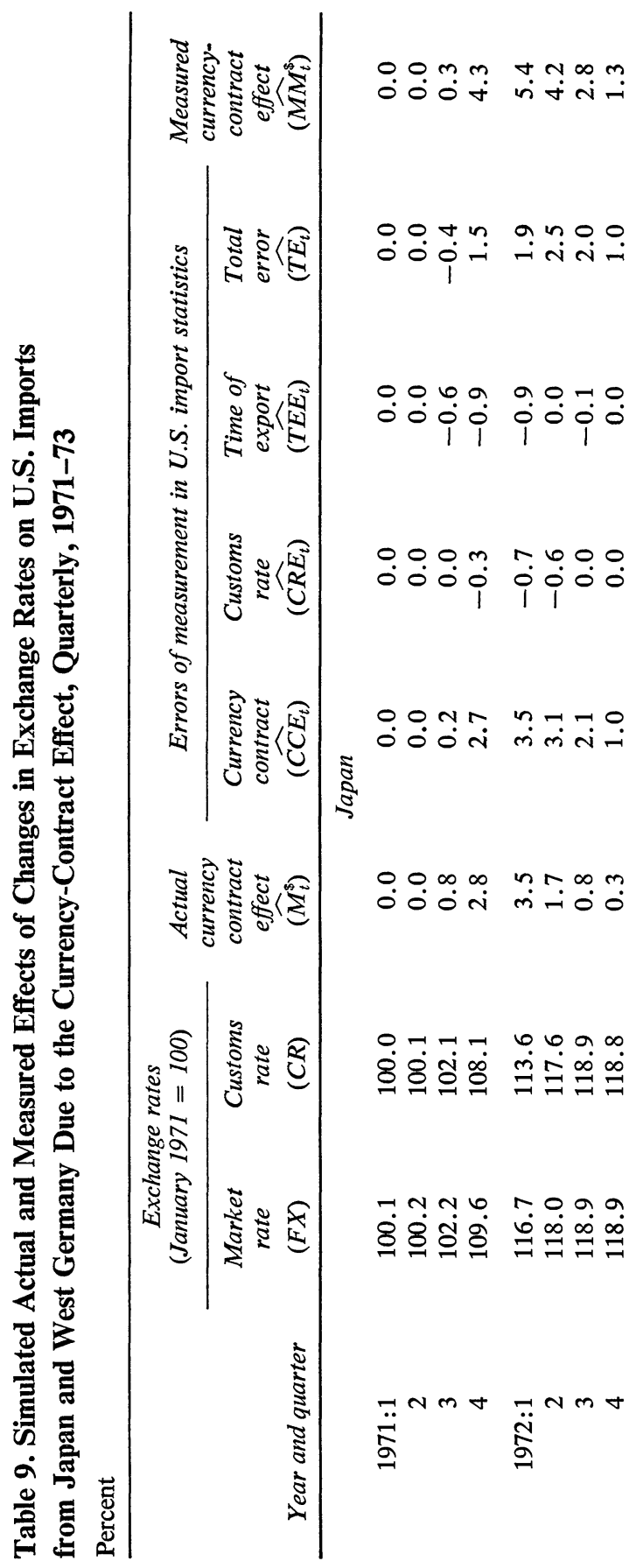




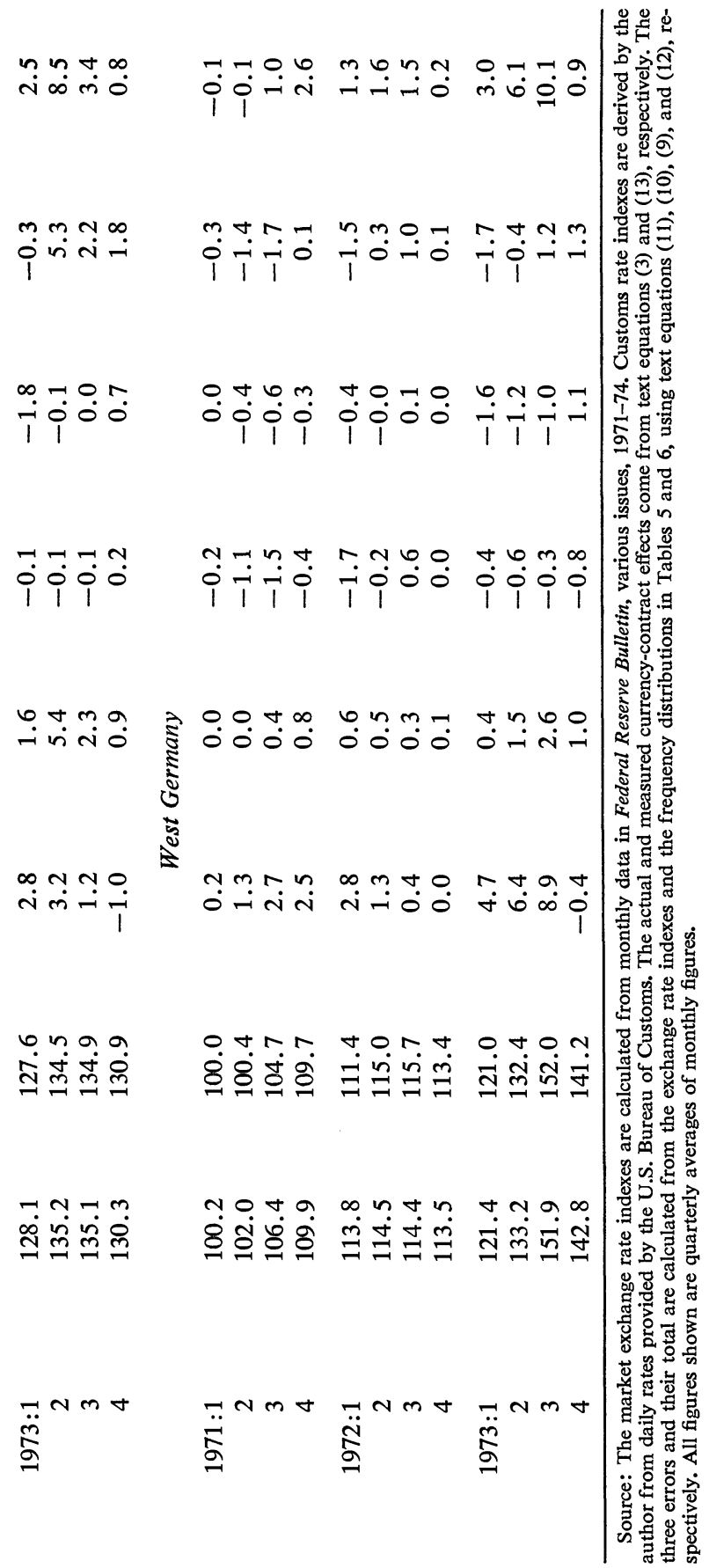


the difference between the currency-contract effects reflected in the import trade statistics and the "true" currency-contract effects. ${ }^{30}$

The total percent error equals

$$
\widehat{T E}+\widehat{C C} E_{t}+\widehat{C R} E_{t}+\widehat{T E} E_{t},
$$

where expressions for the three terms on the right-hand side are given by equations (11), (10), and (9), respectively.

The "measured currency-contract effect" on U.S. imports, $\widehat{M M_{t}^{\$}-\text { the }}$ amount by which the U.S. import statistics change due to the effect of alterations in exchange rates on outstanding contracts-is by definition a combination of the actual currency-contract effect, $\widehat{M}_{t}^{\$}$, from equation (3), and the total error- $\widehat{T E}_{t}$-from equation (12):

$$
\widehat{M M}_{t}^{\S}=\widehat{M}_{t}^{\S}+\widehat{T E}_{t} .
$$

Table 9 reports the results of these calculations for Japan and Germany by quarter. The currency-contract error, as expected, is large for Japanindeed, it dominates the total error-but not for Germany. For the four quarters starting in 1971:4, the total error for Japan was around 2 percent; it was at its highest-5.3 percent-in the second quarter of 1973. In all significant cases, imports from Japan were overstated.

Monthly data for total errors are presented in Table $10 .{ }^{31}$ The erratic movements in the monthly data caused by these errors (in addition to the true currency-contract effects shown in Table 8) are illustrated by the sharp swings in the total error: from 0.2 percent to 5.8 percent from March to April 1973 for Japan; and from -3.2 to 3.8 percent from July to August 1973 for Germany.

The total errors are smaller for Germany, reaching a quarterly maximum of 1.3 percent in 1973:4 and a minimum of -1.7 percent in 1971:3 and 1973:1. In six of the twelve months of 1973, the monthly error exceeded 2 percent in absolute value. Quarterly understatements (dominated by the customs-rate error) occur through most of 1971 and in 1972:1. The time-of-export error produces understatements in 1973:1 and 1973:2, while the currency-contract error is a source of overstatement in 1973:3

30. There are several ways to measure these errors, and the results are not invariant to the order in which they are calculated. In this presentation, interactions among the errors are included in one or more of the three terms rather than written explicitly as a fourth term.

31. A breakdown of the monthly errors into their three components is available from the author on request. 
Table 10. Total Error in the U.S. Import Statistics for Japan and West Germany Due to Improper Measurement of Currency-Contract Effects, by Month, 1971-73

Percent

\begin{tabular}{lrrrrrrr}
\hline & \multicolumn{3}{c}{ Japan } & & \multicolumn{3}{c}{ West Germany } \\
\cline { 2 - 3 } \cline { 6 - 7 } Month & \multicolumn{1}{c}{1971} & 1972 & 1973 & & 1971 & 1972 & 1973 \\
\hline January & 0.0 & 1.5 & 0.6 & & -0.2 & -1.0 & -0.3 \\
February & 0.0 & 2.2 & -1.7 & & -0.4 & -1.6 & -2.6 \\
March & 0.0 & 2.0 & 0.2 & & -0.3 & -2.0 & -2.2 \\
April & 0.0 & 1.8 & 5.8 & & -0.0 & -0.4 & 1.4 \\
May & 0.0 & 2.8 & 5.9 & & -1.7 & 0.8 & -0.2 \\
June & 0.0 & 2.8 & 4.1 & & -2.6 & 0.6 & -2.3 \\
July & 0.0 & 2.2 & 2.9 & & -1.5 & 0.5 & -3.2 \\
August & -0.1 & 2.0 & 2.1 & & -1.6 & 1.3 & 3.8 \\
September & -1.2 & 1.8 & 1.6 & & -2.0 & 1.4 & 3.2 \\
October & 0.7 & 1.3 & 1.4 & & -0.5 & 0.7 & 1.8 \\
November & 2.4 & 1.0 & 2.4 & & 1.1 & 0.0 & 1.7 \\
December & 1.6 & 0.7 & 1.6 & & -0.4 & -0.3 & 0.4 \\
\hline
\end{tabular}

Source: Sum of the three errors discussed in the text; see equations (9), (10), and (11).

and 1973:4. In sharp contrast with the results for Japan, the positive and negative errors for Germany are roughly offsetting. That result emerges even though the currency-contract error is consistently positive for both countries and the other two errors generally negative for both.

\section{Summary and Conclusions}

This paper has examined the currency contracts of U.S. imports from Japan and West Germany in fiscal years 1971 and 1973. These two countries were chosen, first, because they account for significant shares of U.S. imports (16 percent and 8 percent in 1971, respectively), and second, because large changes have occurred in their exchange rates in the last five years: from January 1969 through December 1973, the dollar cost of the deutsche mark in foreign exchange markets rose by 51 percent while that of the yen rose 28 percent; approximately two-fifths of the deutsche mark appreciation and one-third of the yen appreciation occurred in 1973. A sample of 564 U.S. customs invoices was used to establish the currency denomination of contracts for the two countries; 488 of these invoices were used to establish the lags from order to delivery, that is, the lengths 
of the currency-contract periods. These investigations have yielded ten conclusions.

(1) From the pooled samples from both fiscal years, 79 percent of the contracts for U.S. imports from Germany were denominated in deutsche marks, 17 percent in dollars, and 4 percent in other currencies. However, the reverse was true for U.S. imports from Japan: 63 percent were in dollars and only 37 percent in yen. The pattern for Japan agrees with Grassman's results for Swedish trade with the United States and Canada while the German results do not.

(2) The study suggests several hypotheses to explain the tendency of the Japanese to denominate their export contracts to the United States in dollars, which include the following: the long postwar stability of the yen exchange rate; the relatively mild risk aversion on the part of Japanese exporters; use of the currency of contracts as a form of nonprice competition; exemption of dollar-denominated contracts from certain types of financial controls; and differential financing charges that stimulate banks to encourage dollar-denominated contracting. German exporters are responsive to like considerations, but in their case, the effect encourages them to denominate their export contracts in deutsche marks: revaluations in the deutsche mark since 1961, possibly greater relative risk aversion by exporters, and less use of the currency of contract as a form of nonprice competition to increase export-market shares.

(3) Between 1971 and 1973 the initial pattern of the currency denomination of contracts was accentuated, according to these samples. The proportion of dollar-denominated contracts with Japan increased from 61 to 72 percent and the proportion of deutsche mark-denominated contracts with Germany increased from 73 to 81 percent.

(4) The length of the currency-contract period from the point of view of the exporter (the time from his acceptance of the order to its export) averages 96 days for U.S. imports from Japan and 76 days for those from Germany. ${ }^{32}$

(5) Breaking the U.S. importer's currency-contract period (the time elapsed between acceptance of the order by the foreign exporter and "entry" of the goods through U.S. Customs) into its three parts, I found that for imports from Japan, 96 days passed between order and export; 24 days were required for transportation to the United States; and 12 days elapsed from importation until final entry. The average unweighted total

32. These numbers are averages of the 1971 and 1973 means for the production lags reported in Tables 3 and 4. 
lag is 136 days, with a standard deviation of 101 days. The distribution of the contract lengths is skewed to the right, with a maximum length of 22 months.

For U.S. imports from Germany, the lengths of the three lags are 76 days, 12 days, and 20 days, respectively. The average total lag is 120 days, with a standard deviation of 107 days and a maximum length of 19 months.

(6) As a result of the lag patterns and the currency denomination of contracts for U.S. imports, an unanticipated devaluation of the dollar of 10 percent leads to a 3.7 percent increase in the dollar price of Japanese goods and a 5.8 percent decrease in the yen price received by Japanese exporters in the month following devaluation. In the case of Germany, a 10 percent dollar devaluation leads to an immediate 7.9 percent increase in the dollar price of imports and only a 1.5 percent fall in the deutsche mark price.

(7) The currency-contract effect of devaluation on imports contributes to the downward sloping part of the much-discussed J-curve only in the first month after devaluation; thereafter, "currency-contract imports" contribute to an increase in the J-curve from this low point as the curve asymptotically approaches the original level of imports - the level in the absence of devaluation. Furthermore, currency-contract imports from Japan and Germany cause the increasing part of the J-curve to be concave rather than convex from below. This study indicates that the contribution to the trade balance of the currency-contract effect of devaluation on imports might be described better by a $\gamma$-curve ("gamma curve") than a J-curve.

(8) According to simulations for 1971-73 of devaluation-induced changes in prices and values of outstanding U.S. import contracts from Japan, the dollar prices of imports rose 2 percent to 5 percent per month immediately after devaluation. Comparable simulations revealed that the range of increases was larger and more abrupt for imports from Germany -2 percent to 15 percent per month following devaluation-because of the smaller proportion of contracts in dollars, the shorter currency-contract period, and the larger changes in the exchange rate. Conversely, the declines in the prices of these goods in the exporting country's currency are large for Japan and smaller for Germany.

(9) The customs measurement of U.S. imports following changes in exchange rates involves significant errors. In addition to distorting the response of the U.S. trade balance to dollar devaluation, these errors make it difficult to observe the currency-contract effects empirically. The largest error is 
caused by the tendency the U.S. Customs Bureau has to mark up dollardenominated import contracts on goods subject to ad valorem duties when the dollar depreciates (that is, when the dollar cost of foreign currency rises). This practice caused the trade statistics to overstate U.S. imports from Japan by 3 percent or more in thirteen out of the twenty-eight months from September 1971 through the end of 1973. This error is not as significant for U.S. imports from Germany since most of them are denominated in deutsche marks. However, to the extent that U.S. imports from Japan and Sweden are representative of an overall tendency to denominate U.S. import contracts in dollars, total U.S. imports may be substantially overstated in periods when the dollar is depreciating.

A second error arises from the official application of a fixed exchange rate to value imports within each quarter. This "customs rate," which is set each quarter, is not changed within any quarter unless the market rate departs from it by 5 percent or more. For both countries studied here, this error is usually small, and it is always negative when the dollar is depreciating.

Third, because the customs value of U.S. imports is set as of the date of exportation, changes in exchange rates between the time of foreign export and entry into the United States find no reflection in the U.S. trade statistics. This introduces another negative error in a period of dollar depreciation; the second and third negative errors provide a partial, but not always a complete, offset to the currency-contract error.

The total errors caused by the customs valuation practices range from -0.4 percent to 5.3 percent on quarterly U.S. imports from Japan, or from -1.7 percent to 5.9 percent on the monthly figures. For U.S. imports from West Germany, the range is smaller: -1.7 to 1.3 percent on a quarterly basis, or -3.2 to 3.8 percent on a monthly basis.

(10) From an elasticities viewpoint, the currency-contract analysis performed here on U.S. imports from Japan and Germany implies that in the first round following dollar devaluation and in the absence of hedging, Japanese exporters experience most of the loss on Japanese-U.S. trade while U.S. importers generally take the loss on German-U.S. trade. From a monetary viewpoint, real balances held by the Japanese increase with an increase in the dollar-yen parity while real dollar balances in the United States fall slightly. With Germany, the decline in real balances in the United States is substantial relative to the increase in German real balances. 


\section{Comments and Discussion}

William Branson: This paper makes a major contribution in pointing out the potentially large overstatements of imports after a devaluation, reflecting both the genuine effects of currency contracts and statistical errors. These distortions may have contributed to the widespread belief in 1972 and early 1973 that the devaluation of 1971 was not working. I hope that this study will discourage reliance on such misleading data in the future.

I would like to discuss a few problems I found with the paper, however. First, it seems to me that the capital losses during the currency-contract period may have little, if any, relation to the subsequent adjustment process. The extent to which exporters and importers actually bear the capital gains and losses incident to devaluation depends on the extent to which they hedge against such contingencies on the forward market. However, even if exporters and importers do bear these costs, there is no reason to conclude that they will alter future price and production behavior as a result of these once-and-for-all gains or losses. The experience might conceivably influence expectations of traders about future behavior of exchange rates and might lead to slight portfolio shifts, but otherwise adjustment patterns should be unaffected.

Second, the fact that Magee focused only on the import side of U.S. trade seems to imply that the adjustment process is somehow asymmetric. In reality, no matter how contracts are denominated, the effects of changes in exchange rates will be distributed symmetrically. If one country develops a trade deficit in its currency, the other country will develop a surplus in its currency.

Lawrence Krause: I agree with Branson that Magee deserves our thanks for tackling some nasty problems in the trade data. Though he may be 
telling the nonspecialist more than he wants to know about currency contracts, Magee is presenting valuable new evidence in an unexplored area. He shows convincingly that the errors in the import data can be large-large enough to distort unit-value indexes and perhaps large enough to explain, in part, why some econometric models were underpredicting U.S. imports for the periods after dollar devaluation. In my judgment, the main lesson is: don't take the monthly and quarterly trade data too literally.

A great deal of behind-the-scenes discussion goes into determining the currency in an international trade contract. According to reports circulating in Japan at the end of 1972, for example, trading companies were using an effective exchange rate of 280 yen per dollar, rather than the official rate of 308 yen per dollar, in making dollar-denominated contracts. So their pricing anticipated a change in the exchange rate and the currencycontract effects may have occurred earlier than Magee's calculations indicate. As this example suggests, the true story about the currency denominations of import and export contracts may be complex, and no economist can hope to obtain complete information on these matters. Still, Magee's calculations and corrections are worthwhile. One can only emphasize that the presence of unknown variables necessitates a cautious approach in interpreting and analyzing statistics on short-term changes in the trade balance. The data seem to be least trustworthy during periods of sharp changes in exchange rates, when they play their most important role in policy analysis.

Magee's findings are subject to question on several grounds, however. First, since the invoice sample is small and was not selected at random, the statistical results are unreliable. Second, Magee's divergent findings for Japan and Germany pose obstacles to generalizing the message of the study. Third, the analysis appears to be more applicable to the previous monetary system, with its sudden large changes in parities, than to the current system, with its continual, relatively small, changes in exchange rates. Under the current system, traders should be learning how to adapt, to some extent, to gradual movements in exchange rates.

I would suggest, as a next step in research, an effort to link the trade data to balance-of-payments statistics through a study of the timing of payment for imports and exports in relation to the timing of the exchange of the physical goods. 


\section{General Discussion}

Alan Greenspan wondered whether the implications of Magee's results on U.S. imports from Japan might be verified from Japanese data on exports to the United States. If the physical quantities of U.S. imports and Japanese exports could be matched accurately, product by product, then discrepancies between U.S. and Japanese valuations of these quantities might throw some light on the lags involved in Magee's model. Walter Salant doubted that the necessary matching would be feasible, since disparities between trading partners' data for imports and exports were notoriously large. Seymour Etkin of the Census Bureau reported that, while the bureau was developing some new import series, reconciliation of trading partners' data was still very difficult.

Arthur Okun suggested that the census data on imports ideally should be made less dependent on the procedure the U.S. Customs Bureau uses for valuation. For statistical-as distinguished from tariff-collectionpurposes, the value of imports whose contracts are denominated in dollars should not be marked up when the dollar is devalued. Paul Davidson inferred from the paper that the Japanese central bank actively encourages exports by assuming - or at least sharing - the risks involved in denominating contracts in foreign currency. Magee agreed that there seemed to be an export promotion motive in some Japanese financial arrangements.

Salant expressed interest in the possibility of comparing the behavior of the prices of traded goods around the time of changes in exchange rates that seemed anticipated with the behavior associated with those that were unanticipated. Such a comparison would entail relating price changes to spot-forward differentials. Magee reported that some preliminary work with price series for traded goods showed little correlation between price movements and changes in exchange rates in the very short run, though no attempt was made to connect these with spot-forward differentials.

As a final comment, Magee acknowledged the problems involved in using a nonprobabilistic sample. But he doubted that sampling error could gravely distort his findings on the currency denomination of U.S. imports because of the stratification used in obtaining his sample, the randomness used in obtaining the 1 percent sample (from which his sample 
was drawn), and the weighting procedure used to construct the overall frequency distributions. He felt some confidence in the rough approximation that two-thirds of U.S. imports from Japan were in dollars and fourfifths of those from Germany were denominated in deutsche marks.

Magee disagreed that his analysis is more applicable to the previous system of fixed exchange rates than to the floating system. The experience in 1973 indicates that large changes in exchange rates can occur with floating rates. 